\title{
Para além da ciência e do anthropos: deslocamentos da antropologia da ciência e da tecnologia no Brasil
}

\author{
Fabiola Rohden 1 (D) \\ Marko Monteiro ${ }^{\mathrm{II}}$ (D)
}

\section{Introdução}

A antropologia da ciência e da tecnologia (ACT) experimentou notável crescimento nos anos entre 2010 e 2018 , apontando desafios empíricos e teóricos de grande impacto para a disciplina, os quais, como se argumenta a seguir, trazem perguntas para aqueles elementos mais básicos da disciplina Antropologia tal como a conhecemos. Talvez por isso mesmo a ACT se mostre um campo tão vibrante nos últimos anos. Entre tais desafios, destacamos aqui a questáo da ciência e a do anthropos (ou do humano de forma geral, mas especialmente no que se refere ao humano enquanto objeto de estudo da ciência), que na ACT acabam por se tornar objetos de crítica e de reflexão fundamentais.

No que tange à ciência, deve-se ressaltar que o pensamento científico não é objeto recente da reflexão das ciências sociais ou de linhagens antropológicas dessas ciências desde pelo menos As formas elementares da vida religiosa (Durkheim, 1996) ou o clássico Bruxaria, oráculos e magia entre os Azande
(Evans-Pritchard, 2004) que as distinçôes (por vezes difíceis de estabelecer) entre pensamento mágico e racional-científico são parte do pensamento sobre a sociedade. Desde sempre, portanto, a antropologia e as ciências sociais se propóem à questão da ciência e mesmo da tecnologia, se pensarmos toda a tradição antropológica que se debruçou sobre cultura material, artefatos técnicos e circuitos de objetos como o clássico Kula, descrito por Malinowski (1984).

Sendo a ciência e a técnica problematizadas desde sempre, qual é então a razão de tão grande interesse pela ACT recentemente? A nosso ver, para começar a responder a essa pergunta, precisamos retomar problemas clássicos da disciplina. Tanto no que se refere ao fazer científico quanto no que diz respeito ao estudo do humano enquanto objeto específico e distinto do pensamento, vemos que a produção atual vem produzindo deslocamentos cada vez mais importantes nesses pilares das ciências sociais no geral e da antropologia particularmente. Isso fica visível, argumentamos, por meio da análise

\footnotetext{
'Programa de Pós-Graduação em Antropologia Social, Universidade Federal do Rio Grande do Sul - Porto Alegre (RS), Brasil. E-mail: fabiola.rohden@gmail.com

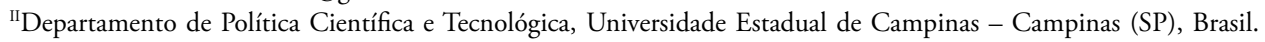
E-mail: carambol@unicamp.br

Recebido em: 07/03/2019. Aprovado em: 27/05/2019.
} 
dos temas enfrentados pelas pesquisadoras e pelos pesquisadores engajados com esse campo, ou mesmo de outros campos, mas em diálogo com os avanços em torno da ciência e da tecnologia.

Tais temas, explorados aqui, incluem os seguintes eixos temáticos, que serão analisados em mais detalhes ao longo do artigo:

- conceitos e métodos da ACT;

- biomedicina e saúde;

- gêneros, sexualidades e tecnociências;

- humanos e não humanos;

- antropologia das técnicas;

- questóes ambientais e desenvolvimento.

Essa tipologia não se pretende de forma alguma exaustiva ou final, mas serve aqui de meio para navegar a grande amplitude e diversidade de temas e abordagens que encontramos ao buscar recuperar a produção da ACT brasileira dos últimos oito anos. Dessa forma, procuramos contribuir não apenas com uma breve revisão desses trabalhos, mas com uma tentativa inicial de melhor conceituar o lugar da ACT na antropologia brasileira como um todo e seu papel de crescente destaque no panorama atual.

$\mathrm{O}$ vigor da produção da ACT recente é perceptível nos artigos, livros e coletâneas, bem como nas teses e dissertaçóes defendidas e nos eventos científicos. Além disso, consolidam-se linhas, grupos de pesquisa e redes, como a própria Rede de Antropologia da Ciência e da Tecnologia (ReACT), que tem tido papel importante no crescimento dessa área de investigaçóes. Em análises atuais do campo antropológico no Brasil, a ACT surge como uma das novidades do período atual (Simóes, 2018), contudo não se trata de um campo novo, embora frequentemente receba o título de emergente. Como explicam Claudia Fonseca e Guilherme Sá (2011, p. 7): "Talvez porque as várias áreas e subáreas disciplinares não se definem de forma tão nítida como antigamente e, assim, ostentam uma diversificação contínua e (para alguns observadores) inquietante".

É preciso dizer, em primeiro lugar, que esse campo tem suas raízes, e mesmo seus pertencimentos paralelos contemporaneamente, em vários outros campos da antropologia. Alguns desses outros subcampos da antropologia poderíamos chamar de mais tradicionais, como corpo e saúde, gênero, religião, etnologia, técnicas. Outros podem ser considerados mais recentes, como estudos de cibercultura, relaçôes multiespecíficas, discussôes sobre desenvolvimento e questôes ambientais contemporâneas, além da investigação antropológica sobre a própria ciência moderna (Latour, 1994) e das recentes discussóes teóricas sobre perspectivismo e ontologia (Jensen e Rödje, 2010; De Castro, 2018). Partilha-se, portanto, de muitas das bases da fundamentação antropológica tanto no que se refere às perspectivas teóricas quanto às orientaçôes metodológicas, mas este artigo busca desenhar os contornos, sempre provisórios e inacabados, da constituição desse campo particular.

Quanto às abordagens teórico-metodológicas, destaca-se a ideia da ciência e tecnologia como produto de complexas redes de associaçóes e articulaçóes heterogêneas (Callon, 1987), de modo que se torna inconcebível a manutenção de proposições analíticas calcadas em distinçôes como natural e cultural ou material e produzido (Latour e Woolgar, 1997; Law, 2009). A inspiração vem não só da própria teoria antropológica, como também dos estudos sociais da ciência e da tecnologia (Martin, 1998; Fischer, 2007) e da crítica feminista da ciência (Haraway, 1989). Nesse último caso, a influência dos estudos antropológicos de gênero e a necessidade de reconhecer a situacionalidade do conheci- 
mento científico, bem como a problematização da ideia de natureza contida nos pressupostos biológicos em torno da produção da diferença sexual e racial, já há muito fomentavam a análise crítica.

Em linhas mais gerais, não se pode conceber a atual ACT sem relacioná-la com avanços recentes nas discussóes dos estudos sobre ciência e tecnologia, que incluem uma atenção etnográfica aos processos da produção da "ciência em ação" (Latour, 2000); ao estudo de performaçóes da materialidade nas práticas (Mol, 2002); além de campos de investigação próximos, como o da Teoria-Ator-Rede (TAR), cujos conceitos estão presentes em boa parte da discussão da ACT, como ator-rede, redes sociotécnicas, coletivos, associaçôes e controvérsias sociotécnicas (Callon, 1987; Latour, 2000; Law, 2009). Temos ainda as discussóes atuais envolvendo redes e híbridos (Strathern, 2014), atores-materiais-semióticos (Haraway, 2004), coprodução (Jasanoff, 2004), ontologias múltiplas (Mol, 2002), materialismo relacional (Law e Mol, 2002), cosmopolítica (Stengers, 2018) e realismo agencial (Barad, 2003), que se tornam fundamentais para dar conta do que é um campo da ACT. Embora não seja possível aprofundar essas discussôes aqui, é preciso frisar que inspiram muitos dos trabalhos considerados.

$\mathrm{Na}$ esfera dos empreendimentos etnográficos, podemos dizer que duas dimensôes, evidentemente articuladas, ganham destaque. A primeira é a que se refere aos estudos acerca da produção do conhecimento técnico-científico, com relevo para as etnografias de labo- ratório, análises da constituição de saberes disciplinares, investigaçóes sobre o papel de novos artefatos tecnológicos na produçáo científica. A segunda diz respeito mais diretamente aos impactos e às articulaçóes das ciências nos usos cotidianos ou na vida concreta das pessoas, o que pode ser traduzido em muitos contextos etnográficos distintos, como as implicações normativas em vários âmbitos, as políticas públicas e tecnologias de governo, as transformaçóes corporais via recursos biomédicos, as novas tecnologias digitais etc.

\section{Mapeando os desafios teóricos e empíricos da antropologia da ciência e da tecnologia}

Ao apresentarmos esse mapeamento, gostaríamos de ressaltar as dificuldades enfrentadas e os limites e as restriçôes do trabalho realizado. Em primeiro lugar, nota-se o problema da definição das fronteiras de um campo que é bastante transversal, como apontamos. Para além disso, em termos pragmáticos, temos a restrição do que é possível agregar no espaço de um artigo e, do ponto de vista operacional, as dificuldades em dar conta de um levantamento mais amplo das publicaçóes do campo. Diante disso, considerando o período ente 2010 e 2018, optamos pela combinaçáo de diferentes estratégias: a análise de publicaçóes em periódicos científicos e coletâneas e o mapeamento das abordagens e temáticas presentes nos eventos científicos, além de informaçôes complementares relativas a disciplinas e trabalhos acadêmicos ${ }^{1}$.

1 Gostaríamos de mencionar que solicitamos a um conjunto de cerca de 40 pesquisadores/as do campo que nos enviassem sugestóes de referências bibliográficas ou de outra natureza. Aproveitamos para agradecer àqueles/as que se manifestaram e de alguma forma contribuíram para esse esforço de sistematizaçáo. De maneira especial, agradecemos a Jéssica Brandt, que colaborou na produção dos dados, e a Marina Nucci, o apoio. 
Uma das vertentes de investigação foram então os periódicos científicos classificados como Qualis A1 em antropologia publicados no Brasil, conforme divulgado pela Coordenação de Aperfeiçoamento de Pessoal de Nível Superior (CAPES) para o quadriênio 2013-2016. Essa é uma classificação restritiva, e importantes revistas foram deixadas de fora em função da falta de condiçôes de se fazer uma pesquisa mais abrangente. De qualquer forma, na medida em que optamos por considerar também as coletâneas e informaçóes relativas aos eventos, esperamos ter dado conta de produzir uma visão panorâmica em duas frentes:

- na publicação de investimentos de pesquisa possivelmente mais consolidados, divulgados nas revistas Qualis A1 e nas coletâneas de artigos;

- na produção emergente de conhecimento registrada nos anais dos congressos da área, apresentada mais brevemente ao final deste trabalho.

Buscamos, em suma, oferecer um panorama reflexivo sobre o que se produziu na ACT brasileira desde 2010, pensando nas temáticas e abordagens mais comuns e buscando explicitar para onde a atenção etnográfica desses trabalhos se voltou. Tentamos organizar esse mapeamento de acordo com o tipo de publicação e também em torno de temas específicos.

A seguir, explicitamos os procedimentos metodológicos utilizados nessa análise. $\mathrm{Na}$ sequência, apresentamos a produção publicada em periódicos e coletâneas e, por fim, acrescentamos informaçóes sobre eventos e campo acadêmico. Terminamos com algumas breves indicaçóes relativas às perspectivas que percebemos nesse cenário.

\section{Os periódicos}

Mediante um levantamento inicial para identificar quais dos periódicos Qualis A1 em antropologia continham artigos concernentes ao campo da ACT, a partir do ano de 2010, foi selecionado um conjunto mais restrito, composto de Mana, Horizontes Antropológicos, Vibrant, Revista Brasileira de Ciências Sociais, Revista Estudos Feministas e Cadernos Pagu. Essa lista não esgota os periódicos que publicaram artigos desse campo, mas auxilia-nos a perceber aquela produção mais visível, publicada em periódicos mais consolidados. Por meio de uma compilação de categorias fundamentadas no conhecimento prévio do campo e também no levantamento feito nos eventos científicos que, de alguma maneira, circunscrevem esse campo no Brasil, realizamos uma seleção dos artigos a serem considerados. A lista de categorias combina palavras-chave como ciência, tecnociência, tecnologia e sociotécnica juntamente com registros mais específicos, como técnica, (bio)medicalização, medicina, cibercultura, internet, gênero, animais, clima e ambiente.

Chegamos então a um corpus de 150 resumos. A etapa seguinte foi a leitura dos resumos e dos artigos para uma verificação mais qualificada acerca do seu possível enquadramento no campo da ACT. Utilizamos, então, como critérios a explicitação de uma perspectiva teórico-metodológica e bibliografia associadas à antropologia da ciência e aos estudos sociais da ciência e da tecnologia, conforme mencionado em linhas gerais na introdução deste artigo, e/ou consideração da produção de saberes e práticas científicas e tecnológicas enquanto objetos de investigação empírica. Isso nos levou à delicada tarefa de tentar distinguir campos 
absolutamente fronteiriços. Por exemplo, no universo dos estudos sobre (bio)medicina e saúde nos detivemos apenas nas pesquisas em que a produçáo do conhecimento biomédico enquanto artefato científico e tecnológico era tomada como central ${ }^{2}$.

É preciso também mencionar a presença da ACT nos dossiês temáticos apresentados em algumas revistas (especialmente Horizontes Antropológicos, Vibrant e Cadernos Pagu). Vale destacar, por exemplo, o número 35 (2011) da revista Horizontes Antropológicos, sobre "Ciência, poder e ética", organizado por Claudia Fonseca e Guilherme Sá, que sintetiza o desafio de produzir ACT a fim de "entender, entre outras coisas, como as pessoas forjam maneiras de agir, nomear e vir a conhecer um mundo em que os objetos 'híbridos' da ciência e da tecnologia ocupam uma centralidade cada vez maior" (Fonseca e Sá, 2011, p. 7). Esse volume contou com colaboraçóes internacionais, como de Donna Haraway (2011), e trouxe artigos versando sobre temas como interação humanos-animais, tecnologias biomédicas de diagnóstico, ensaios clínicos e saúde global, promoção de diagnósticos e medicamentos, hormônios, ancestralidade genética, além de discussôes teóricas.

Outros dossiês dignos de menção são o da revista Vibrant de 2012, "Anthropology, cooperation and development" (volume9, número 1), que ajuda a ilustrar as áreas fronteiriças cuja interseção com a ACT as torna relevantes para pensar o campo no país. Com diversos artigos sobre desenvolvim- ento, empreendimentos extrativos e conflitos em torno de recursos naturais, os artigos abordam uma área de relevância crescente na antropologia e onde as perspectivas da ACT têm bastante força. Temas como conflitos cosmológicos entre povos indígenas (Wright, Kapfhammer e Wiik, 2012) e projetos de desenvolvimento, ou as relações entre saberes locais e regimes globais de propriedade intelectual (Radomsky e Leal, 2012), passando pela mirada etnográfica acerca de cooperação técnica (Cesarino, 2012), ajudam a mostrar a riqueza de uma produção atual que vai muito além da vida de laboratório.

\section{As coletâneas}

Nossa revisão identificou 10 coletâneas de artigos, organizadas no período 2010$2018^{3}$, cobrindo áreas tão diversas quanto antropologia das técnicas (Sautchuk, 2017); perspectivas antropológicas sobre práticas de governo e identificação (Fonseca e Machado, 2015); etnografias da chamada cibercultura (Segata e Rifiotis, 2016); trabalhos oriundos de discussóes realizadas em evento da ReACT (Fonseca et al., 2016a); e, de maneira mais numerosa, pesquisas em torno das denominadas "tecnologias da vida", cujo foco são as ciências e tecnologias ligadas ao corpo, à saúde e à medicina, ainda que com interfaces com outros temas (Premebida, 2011; Fonseca, Rohden e Machado, 2012; Santos, Gibbon e Beltrão, 2012; Mccallum e Rohden, 2015; Fonseca et al., 2016b; Segata e Rifiotis, 2018).

2 Cabe considerar que algumas áreas de fronteira, como biomedicina e saúde, relaçóes humanos-animais, gênero e sexualidade, foram consideradas de forma particular em cada caso, tendo em vista a realização de mapeamentos específicos por outros/as colegas para esta publicação.

3 É importante mencionar que durante esse período também uma série de importantes livros autorais foi publicada. Mais uma vez, por falta de condiçóes de darmos conta dessa grande produção, optamos por nos deter nas coletâneas que, sendo trabalhos coletivos, permitiriam o acesso a um conjunto maior de autores/as e temáticas. 
No que se refere à discussão e retomada da visibilidade de uma antropologia das técnicas calcada em uma tradição francesa e preocupada náo com tecnociência no sentido mais restrito, porém com formas de fazer e relacionar-se com artefatos os mais diversos, em contextos no geral distantes de centros urbanos e laboratórios, destaca-se o trabalho produzido e organizado por Carlos Sautchuk (2010). Outro campo de discussão outrora relativamente afastado dos debates mais visíveis na $\mathrm{ACT}$, mas que ganha grande centralidade com Claudia Fonseca e outros/ as colaboradores/as (Fonseca e Machado, 2015; Fonseca et al., 2016b), são as tecnologias de governo. Perícias, bases de dados policiais, biobancos forenses, vigilância e privacidade, entre outros temas, compóem um campo riquíssimo de discussão que cresce de modo consistente. Também a noção de cibercultura (em um quadro mais geral no qual se discutem as "políticas etnográficas") vem sendo proposta em diversos trabalhos por Theophilos Rifiotis e Jean Segata, dando espaço para produçóes colaborativas focadas tanto no estudo dos processos sociais mediados pelas tecnologias digitais quanto na interface com o campo das ciências da vida (Segata e Rifiotis, 2016; Segata, 2017).

Todavia, o campo de debates cuja relevância o torna incontornável são as ciências e tecnologias do corpo, medicina e governo da vida de modo geral. Desde a investigação da genômica e suas implicaçóes em pesquisas sobre saúde/doença e identidades, passando pela raça/etnia e pelas tecnologias de reprodução, além das formas de pensar o gênero e governar os corpos (particularmente os corpos femininos), chegando às formas de identificaçáo, governo e vigilância de populaçốes (humanas e náo humanas), medicina e definiçốes de vida e morte, os trabalhos agrupados nessa temática vêm tendo impacto estruturante em como avança e se desenvolve a ACT no Brasil e no mundo (Rohden, 2012). Com linhagem feminista ou calcada na antropologia do corpo e da saúde, ou mesmo naqueles trabalhos que dialogam com estudos de raça e Estado, a riqueza e variedade desses trabalhos demonstram como os problemas da produçáo e reconstrução dos corpos e da vida são centrais para qualquer compreensão da ACT.

\section{Eixos temáticos em destaque}

\section{Conceitos e métodos da antropologia da ciência e da tecnologia}

Um dos temas que emergem da análise das revistas são as discussóes sobre o que são os métodos e conceitos centrais de uma ACT. Com o crescimento da ACT, muitos trabalhos começam a tratar de temas e conceitos que cada vez mais são considerados como um subcampo de grande relevância. Além dos artigos de apresentação dos dossiês, que trazem esforços de síntese e análise crítica das perspectivas teórico-conceituais em uso (Fonseca e Sá, 2011; Rohden, Russo e Roca, 2017), temos um conjunto de trabalhos que também investem nessa direção. Os artigos desta seção não oferecem uma visão acabada do que é a ACT, mas cabe mencioná-los pela tentativa que fazem de organizar um conjunto de perguntas específico.

Uma questão sempre presente nas discussões sobre ACT é o papel da etnografia. O método, táo definidor de um campo disciplinar próprio da antropologia, pode em um primeiro momento parecer uma base para se delimitar a ACT: quando antropólogos adotam seu método para investigar a tecnociência, estáo então criando e dando forma a um 
novo tipo de antropologia (Latour e Woolgar, 1997), ao mesmo tempo em que oferecem visóes renovadas sobre o fazer científico (Knorr-Cetina, 1983) e o "laboratório" (Knorr-Cetina, 1992). Em sua revisão acerca das abordagens etnográficas sobre ciência e tecnologia, Monteiro (2012) faz uma tentativa nesse sentido, traçando uma linhagem para a ACT que passa pelos estudos feministas da tecnociência, os chamados "estudos de laboratório" e os estudos sociais da ciência e da tecnologia (ESCT). Para o autor, mais do que o foco temático na tecnociência em si (um olhar para o "centro"), o que torna a ACT específica é o seu foco na tecnociência como "conquista prática". A abordagem das práticas e o questionamento de distinçóes ontológicas caras ao pensamento científico, como "natureza/cultura", abririam novos caminhos na interface entre a antropologia e os ESCT.

Ainda sobre a etnografia, Rifiotis (2016) mobiliza uma categoria importante na ACT brasileira de meados dos anos 2010 , a de cibercultura. Seu texto faz um mapeamento de como o autor percebe o desenvolvimento da etnografia do ciberespaço no Brasil desde os anos 1990. Segundo ele, se nos anos 1990 aconteciam certo deslumbramento com a mediação técnica e um investimento na distinção onlineloffline, na década seguinte se percebeu uma influência maior da noção de uma virada sociotécnica com influências de Latour e da TAR. O fazer etnográfico, por meio da mediação técnica ou em espaços "virtuais", perdeu espaço para debates em torno de redes heterogêneas e em função da incorporação de outras perspectivas mesmo nas investigaçôes sobre a cibercultura.
O questionamento de dualidades (onlineloff-line; natureza/cultura; moderno/ não moderno) é outra das marcas possíveis que identificam a ACT e ajudam a explicar tanto o interesse crescente nos seus debates e eventos quanto a riqueza da sua produção teórica. O dualismo natureza/cultura, assunto mais do que clássico na antropologia, é um dos temas mais abordados, direta ou indiretamente, pela ACT atual, ajudando a descentrar tanto o campo de questóes sobre ciência e tecnologia quanto a própria disciplina como um todo, que passa a cada vez mais fazer esse questionamento sobre suas próprias bases teórico-metodológicas (Latour, 2004; 2011).

$\mathrm{O}$ debate intenso em torno da TAR figura aqui como central, sendo fundamental para qualquer recuperação da ACT no Brasil. É difícil superestimar o impacto que as discussóes acerca de modernidade, agência e não humanos teve sobre os trabalhos hoje categorizados como ACT, o que talvez merecesse um debate à parte. Isso levou a certa predominância dessa visão nos trabalhos que encontramos nessa revisão, o que poderia sugerir homogeneidade teórica na ACT tal qual se configurou nesse período. Ainda que existam outras referências, há que se notar essa grande prevalência de autores/as associados/as à TAR e à chamada pós-TAR (ou pós-actor-network theory - pós-ANT) nas produçôes recentes da disciplina, algo que mereceria problematização mais aprofundada em trabalhos posteriores.

A interface entre etnografias da ciência e tecnologia e a TAR marca muitos trabalhos, de forma mais ou menos explícita. Um artigo que aborda uma tecnologia por

4 Essa categoria não se consolida dessa forma em trabalhos mais atuais, dando espaço cada vez mais à categoria mais geral de antropologia digital. 
esse ponto de vista é o artigo de Spiess e Mattedi (2010) que tenta etnografar a produção de uma rede heterogênea em torno de um processador de texto. Os autores propóem a etnografia de um software, argumentando que há poucos estudos como esse em comparação aos de hardware. $\mathrm{O}$ artigo propóe que o software pode ser pensado como rede heterogênea, afirmando que um software é mais do que um conjunto de comandos que fazem funcionar equipamentos eletrônicos.

O tema é também abordado por João Paulo Bachur (2016), ao discutir a ideia de uma antropologia simétrica e seus limites (Bachur, 2016). Para o autor, Latour não leva sua análise às últimas consequências, ao não radicalizar na sua proposta de superar a distinção entre palavras e coisas (Foucault, 1999) na discussão da realidade. Bachur (2016) aborda a ideia, para ele importante, do discurso como prática material, mas que em Latour não chegaria a se concretizar totalmente. Essa crítica vai na direção oposta às críticas usuais ao autor, que é muito questionado ao sugerir a agência dos não humanos como parte da sua explicação sociológica (que implica um questionamento radical às ciências sociais tradicionais). A presença dos não humanos é outra marca da produção da ACT atual, como se verá, ajudando a distingui-la interna ou externamente ante outros campos como antropologia interespecífica e até mesmo a arqueologia (Neumann, 2008).

\section{Biomedicina e saúde}

No cenário dos estudos sobre as ciências da vida de modo geral e envolvendo especialmente a produçáo do conhecimento (bio) médico e os processos referentes aos marcadores de saúde e doença, a ACT é profundamente marcada por suas raízes nos campos da antropologia da saúde e doença (e também de gênero e sexualidade) desenvolvidos no Brasil $^{5}$, reforçando a ideia da ACT como campo fronteiriço. Destacadamente no que diz respeito aos estudos que abrangem a produção do conhecimento científico (bio)médico, os trabalhos produzidos e orientados por Luiz Fernando Dias Duarte são uma referência fundamental. No que concerne aos investimentos mais recentes, podemos citar suas análises acerca da epigenética (em colaboração com Gláucia Silva) e da neurociência.

No artigo "Epigênese e epigenética: as muitas vidas do vitalismo ocidental", Silva e Duarte (2016) demonstram como tensóes entre perspectivas vitalistas e mecanicistas (ou entre epigenistas e pré-formacionistas) têm sido vetor estruturante nas ciências da vida, ao mesmo tempo em que os termos desse debate vão sendo renovados permanentemente, em razão de marcantes alterações de sentido. Essas tensóes têm consequências também nas próprias ciências humanas, na medida em que reacendem a perene discussão acerca da relação entre natureza e cultura. Já em seu recente artigo sobre a relação entre ciências humanas e neurociências, Du-

5 Sobre os estudos antropológicos sobre corpo e doença em relação aos saberes biológicos no campo científico da saúde, o artigo de Cynthia Sarti (2010) intitulado "Corpo e doença no trânsito de saberes" é uma referência importante. No que diz respeito ao eixo de reflexão e investigaçóes acerca de como a ciência constrói seu conhecimento (ou cultura epistêmica) tomando como foco o aprendizado em medicina, consultar o trabalho de Bonet (2015). Ainda nas fronteiras entre esses vários campos, podemos citar trabalhos como os de Pereira (2012a, 2012b) que discutem, considerando os marcos de uma antropologia simétrica e a grande questão da traduçấo, a relação entre conhecimentos indígenas e biomédicos. 
arte (2018) retoma essa discussão pelo viés da análise de proposiçôes de diversos "naturalismos". Por meio da descrição de exposições realizadas no Museu do Amanhã (Rio de Janeiro), chama a atenção para "o cerebralismo radical das referências à condição humana e o caráter aleatório, assistemático e superficial da tentativa de demonstraçáo da variedade e complexidade da experiência sociocultural da humanidade" (Duarte, 2018, p. 2). Nessa direção, o autor ressalta a importância dos estudos sociais sobre a ciência, especialmente desde uma perspectiva historicizante, na problematização da sacralidade atribuída ao conhecimento científico biomédico.

$\mathrm{Na}$ intenção de ilustrar a porosidade entre estudos sobre biomedicina e a ACT, podemos citar o dossiê "Saúde/doença, biossocialidades e cultura”, organizado por Carlos G. Valle e Sahra Gibbon na revista Vibrant (2015). Embora trate de uma série de temas em saúde/doença, aos quais não podemos nos deter aqui, cabe registrar a confluência de trabalhos que de forma bastante diversa se centram na análise da produção e nos impactos do conhecimento científico.

Jean Segata (2015), por exemplo, por meio de uma etnografia em pet shops e clínicas veterinárias no Sul do Brasil, aborda as transformaçóes recentes nas práticas médico-veterinárias, destacando o surgimento de diagnósticos psiquiátricos em animais de estimação. As relaçôes humano-animal, bem como as formas de produção de conhecimento e transformaçôes nas biossocialidades e natureza, são consideradas pelo autor. Fabíola Rohden (2015), mediante uma análise antropológica das redes sociotécnicas, investiga a medicalização da sexualidade masculina no Brasil centrada na criação de uma nova farmacologia do sexo na passagem para o século XXI, com foco na disfunção erétil e na chamada andropausa. Naara Luna (2015), incorporando abordagens relativas aos direitos humanos e às biossocialidades, estuda as disputas públicas e a presença do discurso dos direitos humanos nos debates sobre o aborto e a pesquisa com células-tronco embrionárias. Já Juliana Macedo (2015) pesquisa as tensóes entre os campos médico e jurídico em torno das concepçóes de risco acionadas nas decisóes judiciais relativas à autorização do aborto de fetos com anomalias fetais incompatíveis com a vida.

Um assunto que vem sendo cada vez mais alvo de investigaçóes diz respeito à genética, em várias práticas possíveis. $\mathrm{O}$ artigo de Waleska Aureliano (2015) é um valioso exemplo de investigaçóes que alcançam as experiências concretas das pessoas na lida com o conhecimento biomédico "inovador" e suas consequências práticas no que concerne a diagnósticos, tratamentos e conformação de sociabilidades e expectativas de futuro. A autora analisa os significados que a noção de herança genética adquire para famílias cariocas afetadas por uma doença rara e hereditária, considerando como essas famílias lidavam com a doença antes e depois do conhecimento acerca dos riscos apresentados nas explicaçóes biomédicas.

Mobilizando um referencial teórico caro à antropologia e aos estudos sociais da ciência e tecnologia, Débora Allebrandt (2015) traz como tema mais geral a importância que o genoma e o próprio laboratório como ambiente capaz de produzi-lo ganham nas últimas décadas. De forma específica, problematiza como ciência e noçôes de herança e transmissão, além de um fascínio pelas raízes biogenéticas, fazem parte da busca das origens de pessoas adotadas no Brasil. Seus dados etnográficos permitem avançar na compreensão de como os conhecimentos 
científicos influenciam as concepções sobre família e parentesco.

O dossiê também conta com um artigo de Claudia Fonseca (2015) inspirado, segundo a autora, tanto nos estudos da ciência quanto na antropologia do parentesco. Com base no estudo do movimento político por reparaçáo encabeçado por filhos de pessoas compulsoriamente internadas por causa da hanseníase, Fonseca (2015) analisa como estruturas coletivas mediadas por diferentes tecnologias produzem formas de socialidade específicas. Para tanto, examina o que chama de "três tecnologias interconectadas" utilizadas pelos atores na configuração dessas conexôes familiares: narrativas orais, documentos escritos e o teste do ácido desoxirribonucleico (DNA).

A conexão entre conhecimento científico, família e parentesco e direitos vai ser uma marca forte no trabalho de Fonseca também em outras publicações. No artigo "Deslocando o gene: o DNA entre outras tecnologias de identificação familiar", publicado na revista Mana (Fonseca, 2016), o foco volta a ser o uso do teste de DNA em investigaçóes judiciais de paternidade, estudado pela autora desde o início dos anos 2000. Agora, no enquadramento de uma antropologia da ciência e na incorporaçáo da perspectiva latouriana da TAR, propóe-se a problematizar a hipótese de uma "genetização" da vida social mostrando as complexidades envolvidas nas experiências cotidianas de uso das tecnologias.

Podemos sugerir que essa linha de reflexão, bem como a centralidade das etnografias, exemplarmente presentes no trabalho de Fonseca $(2015$, 2016), caracteriza boa parte das pesquisas feitas no campo da ACT no Brasil, especialmente no que se refere aos estudos envolvendo o campo das ciências $d a$ vida e seus impactos $n a$ vida das pessoas.
Trata-se de uma apropriação crítica das inspiraçóes teórico-metodológicas da TAR, da ênfase nas associaçôes heterogêneas, dos coletivos, da ideia de coprodução, para citar apenas alguns marcos, profundamente subordinada à investigação das experiências cotidianas (Rohden, 2012). Nessa direção, como bem mostra Fonseca (2016), é necessário trabalhar com uma noção ampliada de tecnologias e conhecimentos na medida em que, nas práticas concretas, diversas tecnociências envolvendo o campo biomédico ou jurídico, por exemplo, se constituem mutuamente.

As pesquisas envolvendo tecnologias ligadas à genômica, é válido lembrar, englobam outros campos de investigaçáo, para além de família e novas configuraçóes da doença. Tanto nesses temas citados quanto em outros que incluem desde processos de racialização e molecularização da saúde/ doença, passando por diferenças raciais e marcadores sociais da diferença (Fullwiley, 2007), além de uma variedade de dinâmicas "sociais" envolvendo os não humanos em escala molecular (Rheinberger, 2000; Rose, 2007), vemos temas caros e clássicos à antropologia sendo reconfigurados pela incorporação da tecnologia como uma preocupação analítica e empírica. A genética é um campo clássico de exploraçáo da ACT desde sempre, como mostram estudos clássicos sobre o DNA enquanto metáfora (Keller, 2009), ou a análise muito influente de Rabinow (1999) sobre biossocialidade. Nas pesquisas mais recentes, vemos um florescer pela óptica de uma diversidade crescente de perspectivas.

Um exemplo dessa diversidade são alguns estudos importantes sobre ancestralidade, genética e raça/etnia, como o de Gaspar Neto e Santos (2011). As tecnologias ligadas à genética molecular são um campo 
fértil de investigação na ACT há décadas, e sua relevância não diminuiu no período recente. Pelo contrário, desdobram-se pesquisas sobre as diversas controvérsias em torno da racialização dos corpos em âmbito molecular, e reconstituem-se hierarquias e preconceitos em novos termos em torno da molecularização, como é debatido amplamente em anos recentes dentro e fora da antropologia (Keita et al., 2004; Fullwiley, 2007). O trabalho de Gaspar Neto e Santos (2011), que se insere em uma pesquisa maior envolvendo etnografias em três países da América Latina cujos resultados foram reunidos no livro Mestizo Genomics (Wade et al., 2014), merece ser apontado como um dos poucos compreensivos acerca dessa questáo do ponto de vista da ACT e dos ESCT.

Gaspar Neto e Santos (2011) fazem um estudo do material de divulgaçáo de testes genéticos de ancestralidade em três países: Estados Unidos, Inglaterra e Brasil. Em cada um deles, os significados e sentidos dessa tecnologia adquirem cores distintas. Os autores argumentam que os estudos de "biologização" evocados por Paul Rabinow (1999) e outros (Gibbon e Novas, 2007) na virada do século XX para o XXI passam a contar cada vez mais com exemplos etnográficos. Nos Estados Unidos, os testes permitem a reconexão dos negros norte-americanos com a ancestralidade africana, ao mesmo tempo fortalecendo laços com o continente e quebrando a categoria genérica de "africanoamericano". O teste genético tem um caráter profundamente transformador da percepção de si das pessoas. $\mathrm{Na}$ Inglaterra, houve um movimento semelhante na publicidade: o estabelecimento de conexôes ancestrais com grupos étnico-raciais por meio de uma ancestralidade construída a posteriori com base em elementos moleculares. No Brasil, o foco encontrado pelo estudo foi concretizar as teorias de mistura genética táo influentes na antropologia e sociologia.

Ainda nos cenários dos estudos acerca das ciências da/na vida, outro eixo geral se refere a reflexôes concernentes à medicalização e à farmaceuticalização ${ }^{6}$ de condiçóes humanas, pensadas no quadro de processos globais envolvendo redes variadas e complexas. Em dada direçấo, isso se traduz, por exemplo, na tentativa de entendimento da preeminência da lógica do aprimoramento individual (mediante recursos farmacológicos e cirúrgicos associados à otimização e ao desempenho), em contextos recentes, por vezes em conflito com a manutenção da saúde. Essa tensão tem requerido o aprofundamento de um debate teórico que problematize as novas formas de subjetivação centradas no investimento pessoal via transformaçóes corporais, nas quais os recursos biomédicos considerados inovadores se tornam centrais (Rohden, 2017). Particularmente, os estudos associados aos eixos de gênero e sexualidade têm caminhado nessa direção, como será explicitado mais adiante.

Em outra abordagem possível, os processos de farmaceuticalizaçấo são analisados tendo em vista a dinâmica de grandes intervençôes farmacêuticas pensadas à luz dos problemas envolvendo a saúde global. Nessa linha, João Biehl (2011) explora seus estu-

6 Williams, Martin e Gabe (2011) ponderam que, enquanto a medicalização é a tradução de fatos não médicos em termos médicos, ampliando o campo de atuação da medicina, a farmaceuticalização se refere à "tradução ou transformação de condiçōes, recursos e capacidades humanas em oportunidade para intervenção farmacêutica" (Williams, Martin e Gabe, 2011, p. 711, tradução nossa). 
dos etnográficos acerca da resposta terapêutica brasileira ao vírus da imunodeficiência humana/síndrome da imunodeficiência adquirida (HIV/AIDS) e suas repercussōes nos âmbitos de governo, mercados, sistemas de saúde e vida pessoal, chamando a atenção para as singularidades dos contextos e das vidas concretas das pessoas.

\section{Gêneros, sexualidades e tecnociências}

A interface pujante entre o campo dos estudos em ciência e tecnologia e os estudos de gênero e sexualidade, como já mencionamos, está profundamente ancorada no projeto de crítica feminista da ciência que vem se constituindo de maneira sólida há bastante tempo (Bleier, 1984; Fausto-Sterling, 1985; Birke, 1986; Oudshoorn, 1994; Haraway, 1995, 2004). Esses estudos têm produzido uma análise crítica da produção científica moderna acerca das supostas bases naturais e imutáveis que determinariam sexo, gênero e sexualidade. De maneira especial, as ciências biomédicas têm sido profícuas em redesenhar variadas formas de "substancialização" da diferença, em contornos dualistas inspirados pela oposiçâo natureza/cultura (Rohden, 2008). No conjunto de artigos aqui analisados, essa interface revela-se na produção de dossiês em periódicos da área de antropologia, como o número 47 da Horizontes Antropológicos (2017), dedicada ao tema "Gênero e sexualidade, saberes e intervençôes", e mais particularmente na Revista Estudos Feministas e Cadernos Pagu, nas quais o cruzamento entre gênero e ciência tem ocupado espaço importante.

No caso da Cadernos Pagu, o dossiê publicado nos números 48 (2016) e 49 (2017) intitulado "Gênero em ciências: histórias e políticas no contexto ibero-americano" tem relevância peculiar, na medida em que se faz uma discussão específica acerca da consolidação desse campo ao longo dos últimos 10 anos. As organizadoras enfatizam a diversidade de temas e abordagens em curso, como a participação de mulheres nas ciências, gênero no discurso médico e na produção e promoção de medicamentos. Quanto às perspectivas adotadas, ressaltam a exigência de considerar como todas as ciências são necessariamente humanas e "as culturas científicas socialmente construídas, engendradas, localmente situadas, contingentes, com suas historicidades específicas" (Lopes e Sombrio, 2017, p. 1). Nota-se, nesses números, a predominância de análises provenientes de outros campos disciplinares que enfocam, sobretudo, a presença das mulheres e as diferenças de gênero na produção de conhecimento, programas e políticas científicas e em várias áreas tecnológicas. Essa linha de investimentos aparece também nos artigos que traçam panoramas acerca do campo de gênero, ciência e tecnologia no Brasil (Minella, 2013; Costa e Feltrin, 2016; Lima e Costa, 2016; Freitas e Luz, 2017). Contudo, como pretendemos ilustrar, não é particularmente nessa direção que se insere a produção mais singular $\mathrm{da}$ antropologia.

Gostaríamos de ressaltar o panorama analítico elaborado por Luzinete Minella na Cadernos Pagu (2013) a respeito da interseccionalidade, especialmente pensando no eixo de raça/etnia. A autora aponta que, no que se refere à manutençáo de assimetrias, os estudos têm salientado aspectos relacionados a gênero, geração e condição socioeconômica das mulheres, contudo verifica-se ausência do privilégio à dimensão de raça/etnia. É preciso mencionar que, no levantamento que realizamos, com poucas exceçóes, como no caso dos estudos sobre raça e genética, essa discussão ainda está pouco presente nos estudos da 
ACT, o que nos leva a destacar a importância de que seja cada vez mais incorporada a eles.

No que concerne a uma produção mais especificamente antropológica, nas interfaces entre gênero, ciência e tecnologia, observa-se um caráter particular. Trata-se da produção de uma abordagem que combina teoria antropológica, estudos feministas da ciência e estudos sociais da ciência e da tecnologia na análise etnográfica das chamadas ciências da vida por meio de suas interfaces com a dimensão do gênero e outros marcadores, especialmente a sexualidade. A área das biociências, de modo geral, encarnada em ramos como genética, medicina reprodutiva, medicina sexual, endocrinologia, neurociências, tem sido estudada tanto nas suas redes de produção quanto nos seus variados usos cotidianos nas vidas concretas das pessoas.

O dossiê publicado na Horizontes Antropológicos 47 (2017) traz um exemplo do conjunto de temáticas que têm caracterizado esse campo de estudos. As organizadoras enfocam nas conexóes entre os estudos de gênero e sexualidade e as interfaces entre ciências, tecnologias, sociedade e poder

tendo como foco as análises relativas às redes que envolvem desde a produção de conhecimentos até suas repercussões relacionadas a novas formas de entendimento do sujeito em diversos cenários contemporâneos, incluindo os recentes processos de (bio) medicalização em curso e o surgimento de distintas formas de (bio) sociabilidade e subjetividades (Rohden, Russo e Roca, 2017).
A “Apresentação" desse volume traz também uma proposta de síntese das abordagens teóricas que têm se destacado. $\mathrm{O}$ postulado do gênero como performado nas práticas, via inspiração em Judith Butler (1993), ganha aqui novos contornos, na medida em que é expandido para a produção e intervenções científicas. Ou seja, o gênero também se produz nas ciências, assim como as ciências coproduzem as normas e performances de gênero. Temos aí um caminho fecundo para muitas investigaçóes que, de modo especial, têm se dedicado não só à análise do conhecimento científico e seu caráter normativo, como também às suas interferências nas múltiplas práticas concretas das pessoas. No que diz respeito de forma singular às intervenções biomédicas, ganham relevo as proposiçôes teóricas que visam dar conta dos processos de materialização em cena e suas correlativas relacionalidades, como muitos trabalhos têm indicado (Rohden, Russo e Roca, 2017) 7 .

Por meio de investimentos etnográficos singulares e inovadores, as/os antropólogas/ os brasileiras/os têm se empenhado em uma incorporação crítica dessas inspirações teóricas e desenhado certos mapas do campo. Marina Nucci (2018), por exemplo, trabalha especificamente sobre a relação entre ciência, gênero e feminismo ao tomar como objeto de investigação o grupo de pesquisadoras da área de gênero e ciência conhecidas como "feministas biólogas" e a rede internacional interdisciplinar de "neurocientistas feministas” estabelecida em 2010 chamada Neuro-

7 Nessa linha podemos destacar as contribuiçóes de Donna Haraway (1995, 2004), Annemarie Mol (2002, 2013), Karen Barad (2003, 2007), Celia Roberts (2007), Myra Hird (2004, 2009), Amade M'Charek (2010), entre outras. 
Genderings $^{8}$. Nesse caso, o próprio grupo investigado incorpora as discussóes teóricas do campo de gênero e ciência, levando Nucci (2018) a ter de lidar com várias dimensões analíticas comprometidas com o debate em torno dos ideais de cientificidade e a crítica feminista.

No artigo "(Des)fazer corpo, (re)fazer teoria”, Paula S. Machado (2014) traça um balanço da produção acadêmica nas ciências humanas e sociais sobre intersexualidade e sua articulação com a produção latinoamericana, no qual tem destaque a produção feminista ligada ao campo dos estudos da ciência. Particularmente, os investimentos da biomedicina em torno das origens da "diferença sexual" e de explicações hormonais impactaram de modo contundente a percepção acerca da intersexualidade no mundo ocidental, em grande medida permeada por concepçóes patologizantes.

Essa atenção acerca de como a produção biomédica tem sido insistente na delimitação da diferença entre os gêneros e nas prescriçóes sobre as sexualidades permitidas ou condenadas tem sido marca importante nessa linha da ACT. Além disso, as investigações em torno dos hormônios, e mais especialmente no que se refere à conformação de uma preeminência da lógica hormonal como metáfora de entendimento do humano (Oudshoorn, 1994; Roberts, 2007; Rohden, 2008), têm sido profícuas. O uso controverso de testosterona por mulheres cisgênero, de modo a não ultrapassar as barreiras que poderiam provocar algum tipo de "masculinização", mostra de forma contundente a preeminência de certos padróes de gênero e de sexualidade que regulam a utilização de recursos biomédicos e as novas formas de administração bioquímica de si (Rohden, 2017).

De forma particular, a insistência nessa lógica hormonal da diferença, bem como as percepçóes concretas acionadas pelas pessoas quanto à potência dos hormônios, para além do entendimento de contextos específicos, têm permitido um adensamento das discussôes teóricas dos limites como natural/artificial ou biológico/social. Exemplo disso é a discussão feita no artigo "Os hormônios te salvam de tudo" (Rohden, 2018), em que se argumenta o caráter complexo e contínuo da produção de subjetividades e transformaçóes corporais com o uso de recursos biomédicos, nas quais as dimensóes discursivas e materiais não podem ser pensadas separadamente. Por meio da noção de "realismo agencial" de Karen Barad (2003, 2007), é feita uma análise do próprio dispositivo do implante hormonal, considerando as interferências produzidas pelo tipo de materialidade empregada pelo artefato e pelos hormônios. A aparente invisibilidade do implante articula-se à ideia de que não se trata de um "remédio" associado a outras formas, como comprimidos orais ou injeçôes.

Essa vertente analítica é bem explorada no artigo de Daniela Manica e Marina Nucci (2017) que analisa o desenvolvimento e as controvérsias relativos aos implantes subcutâneos de hormônios no Brasil. Um dos pontos interessantes do trabalho é a explicitação da associação comumente feita entre esses implantes (cápsulas de silicone microporoso), acessíveis no mercado há algum tempo, e os chamados chips (placas de silício e titânio ativáveis por redes de dados digitais), que ainda não estão disponíveis. As autoras ressaltam, entre outros aspectos, as conexôes

8 Mais informaçôes disponíveis em: <https://neurogenderings.wordpress.com/>. Acesso em: 3 maio 2019. 
com o mercado da medicalização ligado a processos vitais, especialmente envolvendo gênero, sexualidade e reprodução. Sobretudo no que se refere à associação entre contracepção e tecnociência, os estudos de Manica (2011) têm explorado as complexidades da produção dos contraceptivos hormonais, também nas alteraçóes dos ciclos menstruais e proposiçáo de supressão da menstruação, e sua pertinência para questionar as fronteiras entre natureza e cultura.

De certa forma, esses trabalhos têm explorado as conexóes entre a produção científica biomédica, diferentes níveis de circulação de conhecimentos associados a essa produção (do mais acadêmico ao mais popular) e o estabelecimento de novos mercados e práticas de consumo, demarcados por normas de gênero, que se expressam também em corpos, comportamentos e modos de subjetivação. Chama a atenção, particularmente, a inspiração no trabalho de Ludwig Fleck (2010) não só para pensar o enraizamento social do conhecimento científico e biomédico e sua articulação com as protoideias pré-científicas, como também para avaliar os trânsitos implicados nas passagens entre conhecimentos esotéricos (especializados e acadêmicos) e exotéricos (que dizem respeito a circuitos mais amplos de divulgaçáo).

O caso das chamadas drogas prossexuais (medicamentos destinados a tratar problemas como disfunção erétil ou falta de desejo sexual), por exemplo, tem sido valioso para compreender a conformaçáo de certas masculinidades contemporâneas. No artigo "Homem com ' $\mathrm{H}$ ': ideais de masculinidade (re)construídos no marketing farmacêutico", Faro et al. (2013) recorrem ao material publicitário relativo às drogas para tratamento da "disfunçáo erétil" para analisar os discursos do marketing farmacêutico. Concluem que as propagandas voltadas aos médicos veiculam novas concepçóes relacionadas a categorias nosológicas ao mesmo tempo em que reforçam noçôes tradicionais de gênero/ sexualidade. Segundo as autoras, "o 'novo homem' biomedicalizado, sexualmente potente, confiante e rígido é um produto híbrido corpo-tecnologia, na fronteira esfumaçada entre natureza e cultura" (Faro et al., 2013, p. 287).

Esse argumento coaduna-se com as investigações feitas por Fabíola Rohden $(2011,2015)$ acerca da criação de uma nova farmacologia do sexo na passagem para o século XXI, com foco na disfunção erétil e na chamada andropausa, ou distúrbio androgênico do envelhecimento masculino. Mediante a análise da produção científica e da trajetória da construção dessas condições como fenômenos de interesse público e mesmo de sua aceitação em associações médicas e instâncias governamentais, aponta o surgimento de um processo inédito de medicalização do homem e da sexualidade masculina que nos anos recentes tem se apoiado na promoção do hormônio testosterona.

O trabalho de Faro e Russo (2017) segue em uma perspectiva paralela, ao focalizar a articulação entre pesquisa biomédica e indústria farmacêutica, por meio da análise de como o medicamento Intrinsa (um adesivo de testosterona destinado a aumentar o desejo sexual em mulheres) é apresentado em periódicos biomédicos. As autoras revelam as estratégias adotadas nos ensaios clínicos que permitiram a expansão do mercado potencial para o remédio, na medida em que a testosterona passou a ser associada também a tratamentos antienvelhecimento e à promoção do "bem-estar". Já o foco de Lucas Tramontano (2017) recai sobre como são apresentados os chamados hormônios sex- 
uais em manuais de ciências básicas adotados no ensino de graduação em saúde no Brasil. De acordo com o autor, permanece "uma concepção dos hormônios sexuais como mensageiros químicos do gênero, num processo que confere características estereotípicas de masculinidade e feminilidade às próprias moléculas" (Tramontano, 2017, p. 163).

Esses processos de medicalização, farmaceuticalização e mesmo molecularização do gênero e da sexualidade, tão presentes nos casos envolvendo a promoção e o uso de testosterona, também se traduzem na ascensão de outro hormônio, a ocitocina. Fabíola Rohden e Fernanda V. Alzuguir (2016) demonstram como a ocitocina é um novo artefato tecnológico, capaz de capitanear, ao mesmo tempo, as explicaçóes acerca das supostas diferenças biológicas entre os sexos e as expectativas de aprimoramento individual. O foco de investigação foi a divulgação de descobertas científicas em torno desse hormônio em diferentes veículos de comunicação no Brasil, nos quais é frequentemente apresentado como o "hormônio do amor", traduzindo uma nova imagem bioquímica das relaçóes afetivo-sexuais. Importa ainda que as matérias estudadas se destacam por seu caráter de orientação pessoal, conformando o que se pode chamar de um campo de "autoajuda científica", no qual ciência, jornalismo, divulgação e autoajuda se misturam em diferentes veículos de comunicação. Esse trabalho apoia-se nas críticas que Nelly Oudshoorn $(1994,2004)$ tem feito aos estudos sociais da ciência em função de sua dificuldade em incluir a dimensão de gênero. Inspirada na concepção de Butler (1993) do gênero como repetição ritualizada de convenções, Oudshoorn (2004) sinaliza que as tecnologias são fundamentais nos processos de estabilização e desestabilização das convençóes de gênero, criando novas performances ou reforçando as já existentes.

\section{Humanos e não humanos}

A ACT vem abrindo ricos diálogos com perspectivas que poderíamos chamar de póshumanistas, no sentido de abordagens que descentram o humano, o anthropos, do foco conceitual da disciplina. Tal movimento não é banal e envolve tanto as críticas teóricas apontadas pela ACT quanto as recentes discussóes sobre as relaçóes entre humanos e animais, tão importantes em debates como os mobilizados na etnologia, entre outros (Vander Velden, 2012). Esse descentramento do humano também não é novo e pode ser traçado de forma direta desde os debates etnográficos de Strathern (1988), por exemplo, ou da crítica feminista (Haraway, 1991), algo que não aprofundaremos aqui.

Nos trabalhos levantados para este artigo, vemos uma preocupação que vai desde a exploração etnográfica dos animais na prática científica até consideraçóes sobre o papel dos não humanos em fenômenos de escala maior, envolvendo o governo dos corpos e dos saberes. Em todos eles, vemos a centralidade analítica e heurística desse descentramento do humano, desbravando caminhos para perguntas fundamentais sobre dinâmicas contemporâneas e ainda pouco exploradas pela comunidade antropológica.

A insistente questão da agência dos não humanos, tão trabalhada e debatida na TAR, ganha contornos diversificados nos trabalhos atuais. Iara Souza (2017a; 2017b), por exemplo, ajuda a renovar tanto as investigaçôes sobre laboratórios quanto as pesquisas a respeito das relaçóes com animais nos seus trabalhos a propósito de animais de laboratório. Ao perguntar-se no tocante aos 
afetos existentes entre cientistas humanos e camundongos usados em seus experimentos (Souza, 2017a), por exemplo, traz à tona seu papel de "trabalhadores da ciência", quando participam de forma útil aos humanos, bem como nos momentos em que seus comportamentos demonstram resistência às práticas de experimentação. A ideia de trazer a categoria afeto para estudos de laboratório renova a perspectiva que trata da prática científica como mais do que pura objetividade e também coloca foco analítico nos animais enquanto agentes cruciais dessas práticas.

Em outro trabalho, seu olhar etnográfico trata da produçáo da comensurabilidade entre corpos humanos e não humanos, movimento tão central para possibilitar as verdades ali produzidas (Souza, 2017b). Tal comensurabilidade, como mostra sua etnografia, depende das diversas relaçóes estabelecidas entre humanos e não humanos ao longo dos processos laboratoriais, muitas vezes marcadas por tensóes e resistências. O mesmo tópico é tratado por Marcos Castro Carvalho (2016), cujo olhar etnográfico também se volta para animais envolvidos em pesquisas biomédicas. Para o autor, o inusitado e a "não cooperação" dos roedores é por vezes elemento central na produção de fatos científicos, ampliando o escopo da investigação antropológica nesse tema.

O papel dos não humanos na produção de conhecimento científico é tema bastante consolidado, desde pelo menos os trabalhos de Guilherme Sá com primatas. Sá (2010), em sua pesquisa sobre a relação entre biólogos e muriquis em uma reserva ecológica, mostra como as discussóes acerca de como se dão as relaçóes entre os primatas está profundamente implicada nas ideias e imagens que se fazem em torno das sociedades humanas. As disputas em torno do olhar científico e das pessoas que moram na região trazem à tona elementos que vão ainda além da ciência stricto sensu: definir se o muriqui é pacífico ou náo era importante tanto para a primatologia quanto para pensar a realidade dos humanos naquele local.

O mote explorado por Sá (2010) de que o governo dos primatas é importante para a compreensão do governo dos humanos é retomado por Jean Segata (2017) no seu estudo sobre o Aedes aegypti. Nesse artigo, parte de um dossiê maior a respeito de estudos animais, o autor conjuga diversos interesses: pensar o governo dos corpos e vidas humanos por intermédio de infraestruturas de monitoramento, governo dos animais e estratégias de controle do mosquito. Segata (2017) aqui retoma uma definição de cibercultura já citada, conceito que busca recolocar a ideia de cultura com base nas interfaces tecnológicas do presente, com foco especial em tecnologias digitais. $\mathrm{O}$ monitoramento tecnológico e as estratégias de controle do mosquito são analisados com cuidado etnográfico, mostrando como esses mapas e estratégias de governo intersectam mapas morais e relaçóes sociais de violência, dinâmicas urbanas ligadas à desigualdade $\mathrm{e}$ falta de acesso a infraestruturas básicas e dialogam com elas.

\section{Antropologia das técnicas}

Entre os temas clássicos da disciplina que dialogam diretamente com a ACT, talvez o que mais prontamente converse com esse campo seja o da antropologia das técnicas, objeto de revisão já realizada em momento anterior (Sautchuk, 2010). Sem pretender recuperar as origens dessa tradição, nem aprofundar demasiadamente esse tema, já alvo de revisóes mais densas, merecem, no entanto, menção aqueles trabalhos que, aparecendo 
nesse levantamento mais recente, colocam em discussão conceitos e descriçôes etnográficos a respeito de técnicas, e não necessariamente a tecnociência, muitas vezes associada ao campo da ACT propriamente dito.

Não é adequado, pensamos, reforçar esse contraste ou investir nele, como se tecnologia associada à ciência moderna ou ao capitalismo global fosse menos técnica, ou como se técnicas de pesca de ribeirinhos na Amazônia fossem menos complexas ou mais conectadas com saberes locais do que instrumentação de laboratório. Pelo contrário, trata-se de um campo de discussão essencialmente interligado. Como afirma Mura, em sua discussão etnográfica sobre o guarani-kaiowá do Mato Grosso do Sul (Mura, 2011, p. 98):

Em primeiro lugar, eu percebia que era relevante definir as relações técnicas mais a partir das lógicas de uso do que daquelas de produção. Eram as necessidades de uso que regulavam e definiam se era melhor produzir ou adquirir um objeto, bem como definir sua distribuição e transformação. Em segundo lugar, seguindo a própria ontologia nativa, fui levado a considerar irrelevante a distinção entre "natural" e "cultural" nas concatenaçôes entre elementos do cosmo. Fatores de ordem política, mágica e simbólica podiam concatenar-se sem problemas com elementos químicos e físicos, numa lógica processual. Por sua vez, essa superação metodológica da contraposiçáo entre natureza e cultura me levou a questionar a visão sistêmica que centrava parte significativa de sua epistemologia em torno dessa dicotomia, definindo primeiro o presumido sistema social, cultural, simbólico, semântico, etc. para, em um segundo momento, relacioná-lo, como uma totalidade, à realidade sensível do universo, e assim ordená-lo, conotá-lo, significá-lo, etc.
É importante dizer, no entanto, que o termo antropologia da técnica evoca tradiçôes teóricas e campos de investigação específicos, que convergem para perguntas, abordagens e descriçôes etnográficas com características próprias. Por conta disso, tratamos aqui desses trabalhos em seção separada, mas vale notar que, ainda que oriundos de tradiçóes distintas, esses trabalhos possuem em comum uma atenção etnográfica atenta a modos de fazer e a artefatos em relação com práticas, buscando análises que vão além de uma separação entre humano/ não humano e muito adiante de encontrar os significados atribuídos a objetos. Assim como em toda a ACT, procura-se perceber processos dialógicos entre humanos e artefatos, a produção de corpos e artefatos por meio de técnicas específicas e uma apreensão da processualidade das técnicas com base na atenção para a prática.

Sautchuk e Sautchuk (2014), por exemplo, ao discutirem as particularidades de fazer etnografia sobre técnicas envolvendo tanto a pesca artesanal quanto a etnomusicologia, reafirmam a importância de acionar o "engajamento prático" como estratégia de pesquisa. Ou seja, apreender técnicas envolve também um engajamento particular do pesquisador com os processos e práticas de interesse, levando a dilemas metodológicos não táo diferentes daqueles de antropólogos interessados em etnografias virtuais, por exemplo. No caso de técnicas, aponta-se um dilema particular: como aproximar-se de fenômenos e práticas que se distanciam do verbal? Acostumados a engajamentos permeados de trocas verbais (como entrevistas), como estudamos o ato de pescar, por exemplo?

Uma estratégia mencionada é o uso de imagens. Ao discutir o valor que o uso de 
filmagens teve em seu trabalho etnográfico com técnicas de pesca, Sautchuk (2012) menciona a sua estratégia de mostrar as filmagens em público na Vila Sucuriju, no Amapá. Entre os moradores, havia emoção em comentar as técnicas videografadas e exibidas, discutir a relação dos pescadores com o peixe e comentar sobre a paisagem, especialmente para aqueles que não a conheciam. Segundo o autor, as imagens foram rapidamente incorporadas na economia simbólica local em torno da pesca, auxiliando assim seu próprio envolvimento etnográfico.

Além do engajamento teórico e metodológico com a antropologia visual e o cinema, pesquisadores também buscam inspiração na linguística e em estudos sobre cognição, como na investigação de Gabriel Barbosa e Rafael Devos (2017) acerca de técnicas de navegação. $O$ engajamento prático com as técnicas aqui se remete ao caráter complexo da relação do humano com seu meio e das formas usadas para orientar objetos, como navios, no espaço. Trabalhos como tal mostram a riqueza dos potenciais diálogos dessa tradição com a ACT e com outras áreas pouco exploradas da antropologia.

\section{Antropologia, questóes ambientais e desenvolvimento}

Um conjunto dos mais vibrantes que se destacam nesse mapeamento feito aqui é a emergência com muita força de trabalhos que refletem sobre problemas ambientais e de desenvolvimento. Cabe dar ênfase especial a esse conjunto, pois ele representa um agregado novo e cada vez mais numeroso de investigaçóes cujo escopo combina ao mesmo tempo problemas clássicos e preo- cupações novas da ACT e da própria antropologia. Ao mesmo tempo, por exemplo, em que se beneficia do descentramento do humano e da popularidade dos discursos em torno do Antropoceno (no sentido de uma provável nova era geológica em que o humano consiste em uma força de transformação do planeta, do clima e da geologia) (Crutzen, 2006; Palsson et al., 2013; Latour, 2014), esse conjunto de pesquisas considera problemas clássicos das ciências sociais brasileiras, como o desenvolvimento econômico e tecnológico.

Esse debate é feito com viés totalmente diferente, repensando a centralidade do econômico e seu privilégio epistêmico para falar do desenvolvimento, trazendo à tona problemas até então marginalizados ou simplesmente ignorados, como as zonas de conflito cosmológico e ontológico em jogo no avanço do desenvolvimento, como tem ocorrido no país. Além disso, esses trabalhos muitas vezes ampliam o escopo tradicional da ACT, por vezes demasiadamente associada ao estudo microscópico de práticas de laboratório ou interessada na produçáo do conhecimento e suas dinâmicas, para conjugar a produçáo da tecnociência e sua coprodução do mundo com todas as contradiçóes inerentes a isso, incluindo desigualdades, conflitos e hierarquias.

Essa atenção a temas em escala mais ampla do que o laboratório, que envolve também posiçôes inter e transdisciplinares, pode ser vista por exemplo no dossiê da revista Vibrant em seu volume 14 (2017), "Mining, violence and resistance". Na sombra das tragédias de Mariana e Brumadinho, vemos que o olhar antropológico para problemas de extraçáo de recursos, conflitos ambientais e a produção do capitalismo e suas tecnociências associadas envolve temas 
clássicos e contemporâneos da disciplina, necessários para enfrentar questóes cada vez mais prementes, que colocam nossa existência no planeta em questáo.

Zhouri (2017), por exemplo, na introdução desse dossiê, propóe questôes importantes para a antropologia da mineração que dialogam com a ACT na medida em que implicam questionar-se sobre grandes infraestruturas tecnológicas (de extração de recursos, por exemplo) e sua conexão com relaçóes sociais de poder locais e globais, conflitos e disputas entre grupos. A autora indica também dilemas para a antropologia quando se insere nesses campos, que incluem, entre outros, a demanda por parte dos atores dessas arenas de conflito para que os/as antropólogos/as ajam como especialistas, consultores/as e mediadores/as. Tais demandas, ao mesmo tempo que ampliam o horizonte da prática antropológica nesses campos, multiplicam, segundo Zhouri (2017), os dilemas éticos, metodológicos e morais associados a esse tipo de pesquisa. De fato, tais dilemas são ainda um tópico incipiente na nossa reflexão e apontam caminhos produtivos em um período de multiplicação de desastres envolvendo práticas de extraçáo de recursos.

Nessa direção, muitos elementos importantes desse conjunto de trabalhos ficam patentes: além daqueles já mencionados, o problema metodológico de como lidar com esse tipo de trabalho etnográfico vai forçar o/a antropólogo/a a questionar-se sobre seu possível distanciamento, dadas as pressões tanto para poder aproximar-se do objeto e para participar dos conflitos estudados enquanto um tipo de expertise engajada. O olhar sempre situado do/a antropólogo/a oferece um ponto de vista único e cada vez mais valorizado (e disputado, como fica claro no caso de Mariana, estudado diretamente por Zhouri).

Todavia, os problemas em torno da mineração no país não se limitam aos desastres em Minas Gerais e envolvem conflitos entre diferentes racionalidades, como no estudo de Raquel Rigotto (2017) sobre mineração de urânio no Ceará. Aqui fica clara a disputa entre dois tipos de percepção do território: uma vê a natureza como fonte de acúmulo, outra vê o território como fonte de memória. Para além disso, a autora analisa como a autoridade científica pode por vezes ser usada para legitimar práticas ambientalmente nocivas. A disputa de incertezas em controvérsias científicas frequentemente coloca moradores e locais em desvantagem em relação a técnicos e cientistas. Esse estudo enfatiza um problema analisado por vários trabalhos, uma questão que vai muito além dessa breve revisão: como pensar as epistemologias locais diante do avanço do desenvolvimento e dos grandes projetos extrativistas (Wright, Kapfhammer e Wiik, 2012)? A ACT vem dando uma bela contribuição a esse desafio, mas ele transcende a disciplina e requer muito mais esforços.

Outro tema importante a esse grupo de pesquisas é o conceito de desenvolvimento que aparece de diversas maneiras nos trabalhos aqui analisados. Leticia Cesarino (2012), por exemplo, em outro dossiê da Vibrant, intitulado "Anthropology, Cooperation and Development", faz um bom apanhado da chamada antropologia do desenvolvimento e trata do caso das então emergentes cooperaçôes técnicas que o Brasil tentava fazer com países da África (mostrando o quanto o contexto nacional e global mudou desde então). Seguir os fluxos de expertise e recursos entre países propóe dilemas ainda pouco explorados, 
impondo ao mesmo tempo uma volta a temas tradicionais ou mais comuns na disciplina, como relaçôes geopolíticas, mas pensando por um ponto de vista distinto de outras disciplinas, o papel do saber técnico nessas relaçóes e fluxos. Problemas perenes na antropologia, como a reflexividade que se impóe à produçáo do conhecimento, evocam tratamentos clássicos como o de David Mosse (2006, 2007): qual é o papel do antropólogo enquanto técnico e participante de cooperação? Onde estão ou devem estar nossas lealdades teóricas e práticas em campos em que essas lealdades entram em contradição?

\section{Os problemas emergentes da antropologia da ciência e da tecnologia}

Neste tópico, deixamos o universo das publicaçóes para darmos alguma atenção ao que vem se apresentando de maneira crescente no plano da produção de trabalhos acadêmicos e nos eventos científicos.

Um levantamento no catálogo de teses e dissertaçóes da CAPES é revelador do significativo crescimento do campo desde 2010. A busca pela categoria antropologia da ciência, que abrange também antropologia da ciência e da tecnologia e antropologia da ciência e da técnica, seja na entrada por linhas de pesquisa (o que ocorre especificamente nos casos da Universidade Federal do Rio Grande do Sul - UFRGS e da Universidade de Brasília — UnB), seja por palavras-chave, mostra o total de 61 trabalhos. Destes, apenas sete foram defendidos entre 1998 e 2009, sendo a imensa maioria apresentada entre 2010 e 2018 . São 19 teses de doutorado e 42 dissertaçóes de mestrado. Embora alguns programas multidisciplinares ou de áreas afins apareçam, 48 pesquisas foram conduzidas em programas de pós-graduação em antropologia social (22), antropologia (21), ciências sociais/ antropologia (3) e sociologia e antropologia (2). Outro dado que se destaca é a forte presença de algumas instituiçôes, como a UnB (17 trabalhos), a UFRGS (15) e também a Universidade Federal de Minas Gerais (UFMG) (6), a Universidade de São Paulo (USP) (5) e a Universidade Federal do Rio de Janeiro (UFRJ) (5). A existência de grupos de pesquisa e pesquisadores/as bastante atuantes no campo vinculados a essas instituições permite compreender esse quadro. No que se refere às temáticas, embora não haja condiçóes de tratar delas de modo detido neste artigo, é preciso dizer que são bastante variadas, indicando a mesma riqueza de abordagens e investimentos etnográficos que percebemos na análise dos temas nos eventos e nas publicaçóes da área.

Cabe acrescentar também que no início da última década foram criadas e institucionalizadas as disciplinas de Antropologia da Ciência e da Tecnologia nos cursos da área de ciências sociais e antropologia nas universidades brasileiras como UnB, UFRGS, USP, Universidade Federal de Santa Catarina (UFSC) e Universidade Estadual de Campinas (UNICAMP), em nível de graduação e pós-graduação, embora o tema já fosse alvo de discussão em outras propostas em diferentes cursos e instituiçóes. Uma análise dos programas de curso revela não só uma frequente atualização em relação ao campo internacional, como também a inclusão da produção nacional veiculada em livros, periódicos e trabalhos acadêmicos.

Em função desse já citado crescimento vigoroso, optamos por trazer um breve comentário acerca de como esse tema tem estado presente nos eventos cientificos. Têm destaque aqui as mesas-redondas, os grupos de trabalho e as conferências que ganharam 
cada vez mais espaço nas Reunióes Brasileiras de Antropologia (RBA), nos encontros da Associação Nacional de Pós-Graduação e Pesquisa em Ciências Sociais (ANPOCS), nas Reunióes de Antropologia do Mercosul (RAM), entre outros. Analisamos a pre-

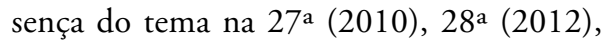
29a (2014), 30a (2016) e $31^{\mathrm{a}}$ (2018) RBA; entre o $34^{\mathrm{a}}(2010)$ e o $42^{\mathrm{a}}$ (2018) encontro da ANPOCS; e na $10^{a}(2013), 11^{a}$ (2015) e 12a (2017) RAM $^{9}$.

Para além disso, é na presente década que se consolidam as ReACT, que foram incluídas na análise, nas quais se concentram de forma mais importante os trabalhos desse campo e se podem perceber mais claramente seus movimentos. Consideramos a $3^{\mathrm{a}}$ (2011), a $4^{\mathrm{a}}$ (2013), a $5^{\mathrm{a}}$ (2015) e a 6a (2017) edição. Resultado da articulação entre vários grupos de pesquisa no campo da ACT, a ReACT tem como intuito promover um debate que discuta o potencial e as contribuições da antropologia na construção de perspectivas acerca das ciências/conhecimentos/saberes, das tecnologias/técnicas/inovaçóes e das relaçóes entre essas ciências e tecnologias e as formas de constituição da vida e do futuro que elas condicionam e que ajudam a coproduzir.

No total, para essa breve análise, foram considerados 20 eventos, tendo sido consultadas as documentaçóes referentes a 45 seminários temáticos, 30 grupos de trabalho e 32 mesas-redondas ${ }^{10}$. No que concerne às temáticas dos trabalhos apresentados, pudemos sistematizá-las de acordo com alguns grandes eixos e categorias-chave, conforme o que foi apresentado nos resumos. Elencamos esses temas de forma descritiva, sem o ordenamento por prioridade ou por importância relativa no campo.

Um dos eixos que articulam questóes mais gerais é o que aglutina discussões referentes a multiplicidades ontológicas $e$ diferentes modos de produzir conhecimentos/ saberes. Nesse tema, agrupamos trabalhos abordando as transversalidades e os embates entre ciências, os saberes tradicionais, a religião e a arte; xamanismo, espiritualidade e ciências; percepção ambiental e ontologias indígenas; saberes musicais; e inteligência artificial. Em outro eixo, pudemos ver a concentração de questóes ambientais, desenvolvimento e territórios. Aqui conjugamos trabalhos que abordam a produção de modos de monitoramento do território e do ambiente; conflitos ambientais, grandes empreendimentos de extração de recursos naturais e as disputas de expertises associadas aos problemas ambientais recentes; relaçôes entre populaçóes tradicionais (indígenas, quilombolas, ribeirinhos) e pesquisadores/ cientistas; processos e disputas de licenciamentos ambientais, conservação marinha e florestal; desastres ambientais e acidentes nucleares; agrobiodiversidade; práticas indígenas de manejo; uso de recursos hídricos; e agricultura e pecuária.

Já no tema politicas públicas e produção de conhecimentos, identificamos investigaçóes sobre as articulaçóes entre ciências e políticas de financiamento à pesquisa; circulação de conhecimento entre cientistas e gestores; políticas científicas; museus e institucionalização das ciências; infraestruturas para produção científica; políticas de inovação; novos ambientes da produção e uso do conhecimento; estratificação cientí-

9 Não foi possível acessar pela internet informaçóes a respeito da 9a RAM, realizada em 2011.

10 As referências aos anais consultados encontram-se na bibliografia. 
fica no Brasil; gênero nas instituiçôes científicas; avaliação de indicadores e periódicos científicos; e ensino de ciências nas escolas. $\mathrm{Na}$ interface com as políticas públicas, tem emergido um conjunto de trabalhos referentes ao tema dos direitos, tecnologias de governo e cidadanias, que incorpora discussôes relativas a biotecnologia na persecuçáo criminal brasileira; tecnologias de identificação e reconhecimento; bancos de dados de perfis genéticos; tecnologias de vigilância; tecnologias biomédicas; produção de laudos; perícias; e serviços que atendem a populaçôes específicas (como crianças e adolescentes em situaçáo de rua).

Outro importante conjunto de investigaçóes centra-se no eixo corpo, saúde, biomedicina e tecnociências. Nesse caso, destacam-se os trabalhos sobre produção, usos e implicaçóes das ciências da vida; análises (históricas e contemporâneas) da construção do conhecimento em saúde, doenças e intervençôes biomédicas; estatuto dos medicamentos e farmaceuticalização de condiçôes de vida (transtornos de humor, déficit de atenção/hiperatividade, hormônios, drogas prossexuais, inibidores do apetite); biossocialidades; neurociências; neuroeconomia; medicina antienvelhecimento; bioarte; reprodução humana em laboratório; estatuto de embrióes e fetos; medicalização da reprodução; diagnóstico e aconselhamento genético; genética de populaçôes humanas; atuação dos profissionais de saúde; protocolos clínicos; regulamentação sanitária; relação entre profissionais e populações específicos; transplantes e artefatos biomédicos de assistência e monitoramento; tecnologias relativas a HIV/AIDS; e uso de classificaçóes racializantes.

Muitas vezes em articulação também com esse eixo, figuram os estudos em torno do eixo gênero, sexualidade e ciência. Aqui, têm relevância as discussóes tangentes a teorias de gênero e crítica feminista da ciência; conhecimento e práticas biomédicas relacionados a gênero e sexualidade (corporalidades, subjetividades e identidades de pessoas trans, intersex e cisgênero; padronizaçáo de corpos e identidades femininos e masculinos); práticas contraceptivas, biopolítica e controle da fertilidade; gênero e mercado; neurofeminismo; políticas públicas e legislação; uso de hormônios; diferenças cerebrais; e raça e gênero nas práticas biomédicas.

Cabe ainda fazer referência ao campo de estudos sobre as relaçóes multiespecificas, que têm aglutinado trabalhos acerca de animais de laboratório; animais humanizados; produção e consumo de produtos de origem animal; relação entre caçadores, fazendeiros e cientistas; manejo de espécies animais; doenças; e proteção animal. Também, apontam ao conjunto de investigaçôes relativas à antropologia digital/cibercultura, que têm agregado as discussóes a respeito de politicas etnográficas; interfaces com raça e gênero; intolerância e violência nas redes sociais; relacionalidades, parcerias amorosas e sexuais e aplicativos; redes de ação coletiva e processos identitários; internet em manifestaçôes públicas e atos políticos; produção de celebridades; produção de valor econômico; pornografia, lan houses populares; videovigilância e videovoyeurismo; idosos e tecnologia digital; internet e autorrepresentaçáo indígena; e inclusão digital.

Por fim, é necessário mencionar a contínua presença dos estudos referentes a concepçóes e usos das técnicas. Nessa linha, destacam-se as discussões no tocante às relaçôes pessoa-técnica-mundo em diversos contextos como pesca, construçáo civil, caça, extração 
da borracha, navegação; técnicas de plantio; práticas alimentares; uso de plantas medicinais; design; ferramentaria de santo, surfe; interação com animais; previsão do tempo; trabalhadores em mercados de rua; rendeiras, capoeiristas; e praticantes de musculaçáo.

Como se pode perceber, há no campo mais geral da ACT que se manifesta nos eventos científicos grande variação temática e de perspectivas. Nesse agrupamento de eixos e subtemas não pretendemos ser exaustivos, já que seria inviável a compilação dos assuntos tratados em cada trabalho específico. Assim, essa descrição pareceu-nos ilustrativa da dinâmica atual desse campo. Ela permite, de alguma forma, uma visão geral dos interesses que têm mobilizado pesquisadores/as no campo da ACT hoje em dia e instiga a refletirmos sobre os cenários atuais e futuros.

\section{Considerações finais}

$\mathrm{O}$ que percebemos quando justapomos as leituras das publicações é, em um plano, uma imensa variedade de objetos. Desde a análise da produção científica em laboratórios, passando por grandes projetos de desenvolvimento, tecnologias da vida etc., são muitos os focos que têm mobilizado pesquisadores/as de diferentes geraçôes, mas principalmente os/as mais jovens. Em outro plano, reconhecemos uma efervescência teórica pautada pela busca de novos horizontes ou pela retomada crítica de referências mais antigas que permitam entender os processos envolvendo a ciência e a tecnologia no mundo contemporâneo, em suas muitas complexidades. Além disso, o que notamos com nitidez é uma procura vigorosa por diálogos transversais, para além de circunscriçóes temáticas já há muito consolidadas. Talvez uma das grandes promessas do campo seja renovar a capacidade que temos de aprender com as diferenças. Nesse caso, tratamos das diferenças decorrentes da comparação etnográfica e de distintas posiçôes teóricometodológicas que têm sido possíveis no encontro promovido pelos/as interessados/ as em uma ACT.

Em termos mais gerais, se fosse possível destacar uma ideia central que parece permear, ao mesmo tempo, como esse campo tem se caracterizado, assim como promovido novos desafios, talvez seja o consistente e permanente problema da reflexividade antropológica e da situacionalidade do/a pesquisador/a cada vez mais associadas a questionamentos sobre a natureza ou o fim das intervençôes tecnocientíficas. Ao analisarmos as múltiplas interfaces entre ciências, tecnologias e sociedades, somos obrigados/as o tempo todo a repensarmos o próprio lugar das ciências, de modo geral, e da ciência antropológica, particularmente. É possível dizer que esse tipo de atenção singular aos lugares e às formas de produçáo de conhecimento e suas variadas possibilidades de materialização em políticas, artefatos, transformaçôes ambientais, corpos e subjetividades tem exigido uma reflexão constante acerca da produçáo de diferenças e desigualdades envolvidas nesses processos. A ACT tem caminhado na pretensão de dar conta da exposiçấo dessas assimetrias (como as de gênero, raça/etnia, classe social, geração, geopolítica), mas ainda há muito o que fazer. A pergunta que permanece nesse horizonte, como inspiração para uma antropologia que se pretende engajada nos problemas contemporâneos, continua a ser em torno de para que e para quem uma ciência ou tecnologia é produzida. 


\section{Bibliografia}

ALLEBRANDT, D. La science de la parente: adoption, genetique et identite parmi les adoptes au Bresil. Vibrant: Virtual Brazilian Anthropology, v. 12, n. 1, p. 141-166, 2015. http://dx.doi.org/10.1590/1809$43412015 \mathrm{v} 12 \mathrm{n} 1 \mathrm{p} 141$

AURELIANO, W. D. A. Health and the Value of Inheritance: The meanings surrounding a rare genetic disease. Vibrant: Virtual Brazilian Anthropology, v. 12, n. 1, p. 109-140, 2015. http://dx.doi.org/10.1590/1809$43412015 \mathrm{v} 12 \mathrm{n} 1 \mathrm{p} 109$

BACHUR, J. P. Assimetrias da antropologia simétrica de Bruno Latour. Revista Brasileira de Ciências Sociais, v. 31, n. 92, p. 1-21, 2016. http://dx.doi.org/10.17666/319209/2016

BARAD, K. Meeting the Universe Halfway: Quantum Physics and the Entanglement of Matter and Meaning. Durham: Duke University Press, 2007.

BARAD, K. Posthumanist Performativity: Toward an Understanding of How Matter Comer to Matter. Signs, v. 28, n. 3, p. 801-831, 2003. http://dx.doi.org/10.1086/345321

BARBOSA, G. C.; DEVOS, R. Paralaxe e "marcação por terra": técnicas de navegação entre jangadeiros na Paraíba e no Rio Grande do Norte. Mana, v. 23, n. 3, p. 343-372, 2017. http://dx.doi.org/10.1590/1678$49442017 \mathrm{v} 23 \mathrm{n} 3 \mathrm{p} 343$

BIEHL, J. Antropologia no campo da saúde global. Horizontes Antropológicos, v. 17, n. 35, p. 227-256, 2011. http://dx.doi.org/10.1590/S0104-71832011000100009

BIRKE, L. Women, feminism and biology: the feminist challenge. Brighton: Harvester, 1986.

BLEIER, R. Science and gender: a critique of Biology and its theories on women. Nova York: Pergamon, 1984.

BONET, O. Sentindo o saber. Educação da atenção e medicina de família. Horizontes Antropológicos, v. 21, n. 44, p. 253-277, 2015. http://dx.doi.org/10.1590/S0104-71832015000200011

BUTLER, J. Bodies That Matter. Nova York: Routledge, 1993.

CALLON, M. Society in the making: The study of technology as a tool for sociological analysis. In: BIJKER, W. et al. (orgs.). The Social Construction of Technological Systems. Cambridge: MIT Press, 1987. p. 83-106.

CARVALHO, M. C. Produzindo Quimeras: Linhagens de roedores, cientistas de laboratório e as vicissitudes da experimentação animal. Vibrant: Virtual Brazilian Anthropology, v. 13, n. 2, p. 160-176, 2016. http://dx.doi. org/10.1590/1809-43412016v13n2p160

CESARINO, L. M. C. D. N. Anthropology of development and the challenge of South-South cooperation. Vibrant: Virtual Brazilian Anthropology, v. 9, n. 1, p. 507-537, 2012. http://dx.doi.org/10.1590/S180943412012000100017

COSTA, M. C. D.; FELTRIN, R. Desafios da Interseccionalidade em Gênero, Ciência e Tecnologia. Cadernos Pagu, v. 47, p. 1-9, 2016. http://dx.doi.org/10.1590/18094449201600470018

CRUTZEN, P. J. The "anthropocene". In: CRUTZEN, P. J. (org.). Earth system science in the anthropocene. Nova York: Springer, 2006. p. 13-18.

DE CASTRO, E. V. Perspectivismo e multinaturalismo na América indígena. São Paulo: Ubu, 2018.

DUARTE, L. F. D. Ciências Humanas e Neurociências: um confronto crítico a partir de um contexto educacional. Revista Brasileira de Ciências Sociais, v. 33, n. 97, p. 1-20, 2018. http://dx.doi.org/10.1590/339702/2018 
DURKHEIM, E. As formas elementares da vida religiosa. São Paulo: Martins Fontes, 1996.

ENCONTRO ANUAL DA ANPOCS, 34., 2010, Caxambu. Anais Eletrônicos [...]. São Paulo: ANPOCS, 2010. Disponível em: <http://anpocs.com/index.php/34o-encontro-anual-2010>. Acesso em: 29 jan. 2019.

ENCONTRO ANUAL DA ANPOCS, 35., 2011, Caxambu. Anais Eletrônicos [...]. São Paulo: ANPOCS, 2011. Disponível em: <http://anpocs.com/index.php/35o-encontro-anual-2011>. Acesso em: 29 jan. 2019.

ENCONTRO ANUAL DA ANPOCS, 36., 2012, Águas de Lindoia. Anais Eletrônicos [...]. São Paulo: ANPOCS, 2012. Disponível em: <https://www.anpocs.com/index.php/36encontro-atual>. Acesso em: 29 jan. 2019.

ENCONTRO ANUAL DA ANPOCS, 37., 2013, Águas de Lindoia. Anais Eletrônicos [...]. São Paulo: ANPOCS, 2013. Disponível em: <http://anpocs.com/index.php/37o-encontro-anual-2013-sp-1400301266>. Acesso em: 29 jan. 2019.

ENCONTRO ANUAL DA ANPOCS, 38., 2014, Caxambu. Anais Eletrônicos [...]. São Paulo: ANPOCS, 2014. Disponível em: <https://www.anpocs.com/index.php/38-encontro>. Acesso em: 29 jan. 2019.

ENCONTRO ANUAL DA ANPOCS, 39., 2015, Caxambu. Anais Eletrônicos [...]. São Paulo: ANPOCS, 2015. Disponível em: <https://www.anpocs.com/index.php/39-encontro>. Acesso em: 29 jan. 2019.

ENCONTRO ANUAL DA ANPOCS, 40., 2016, Caxambu. Anais Eletrônicos [...]. São Paulo: ANPOCS, 2016. Disponível em: <http://anpocs.com/index.php/40o-encontro-anual-2016>. Acesso em: 29 jan. 2019.

ENCONTRO ANUAL DA ANPOCS, 41., 2017, Caxambu. Anais Eletrônicos [...]. São Paulo: ANPOCS, 2017. Disponível em: <https://www.anpocs.com/index.php/41o-encontro-anual-2017>. Acesso em: 29 jan. 2019.

ENCONTRO ANUAL DA ANPOCS, 42., 2018, Caxambu. Anais Eletrônicos [...]. São Paulo: ANPOCS, 2018. Disponível em: <https://anpocs.com/index.php/encontros/papers/42-encontro-anual-da-anpocs >. Acesso em: 29 jan. 2019.

EVANS-PRITCHARD, E. E. Bruxaria, oráculos e magia entre os Azande. Rio de Janeiro: Zahar, 2004.

FARO, L.; RUSSO, J. A. Testosterona, desejo sexual e conflito de interesse: periódicos biomédicos como espaços privilegiados de expansáo do mercado de medicamentos. Horizontes Antropológicos, v. 23, n. 47, p. 61-92, 2017.

FARO, L. et al. Homem com "H": ideais de masculinidade (re)construídos no marketing farmacêutico. Cadernos Pagu, n. 40, p. 287-321, 2013. http://dx.doi.org/10.1590/S0104-83332013000100009

FAUSTO-STERLING, A. Myths of the gender: biological theories about women and men. Nova York: Basic Books, 1985.

FISCHER, M. M. Four genealogies for a recombinant anthropology of science and technology. Cultural Anthropology, v. 22, n. 4, p. 539-615, 2007. https://doi.org/10.1525/can.2007.22.4.539

FLECK, L. Gênese e desenvolvimento de um fato científico. Belo Horizonte: Fabrefactum, 2010.

FONSECA, C. Deslocando o gene: o DNA entre outras tecnologias de identificaçăo familiar. Mana, v. 22, n. 1, p. 133-156, 2016. http://dx.doi.org/10.1590/0104-93132016v22n1p133

FONSECA, C. Time, DNA and documents in family reckonings. Vibrant: Virtual Brazilian Anthropology, v. 12, n. 1, p. 75-108, 2015. http://dx.doi.org/10.1590/1809-43412015v12n1p075

FONSECA, C. et al. (orgs.). Antropologia da Ciência e da Tecnologia: dobras reflexivas. Porto Alegre: Sulinaed, 2016a.

FONSECA, C. et al. (orgs.). Ciência, medicina e perícia nas tecnologias de governo. Porto Alegre: Editora da UFRGS/CEGOVed., 2016b. 
FONSECA, C.; MACHADO, H. (orgs). Ciência, identificaçáo e tecnologias de governo. Porto Alegre: Editora da UFRGS/CEGOVed., 2015.

FONSECA, C.; ROHDEN, F.; MACHADO, P. S. (orgs.). Ciências na vida: antropologia da ciência em perspectiva. São Paulo: Terceiro Nomeed, 2012.

FONSECA, C.; SÁ, G. J. S. Apresentação: Ciência, poder e ética: implicaçôes e desdobramentos antropológicos. Horizontes Antropológicos, v. 17, n. 35, p. 7-23, 2011. http://dx.doi.org/10.1590/S0104-71832011000100001

FOUCAULT, M. As palavras e as coisas: uma arqueologia das ciências humanas. São Paulo: Martins Fontes, 1999.

FREITAS, L. B.; LUZ, N. S. D. Gênero, Ciência e Tecnologia: estado da arte a partir de periódicos de gênero. Cadernos Pagu, v. 49, p. 1-26, 2017. http://dx.doi.org/10.1590/18094449201700490008

FULLWILEY, D. The Molecularization of Race: Institutionalizing Human Difference in Pharmacogenetics Practice. Science as Culture, v. 16, n. 1, p. 1-30, 2007. https://doi.org/10.1080/09505430601180847

GASPAR NETO, V. V.; SANTOS, R. V. Biorrevelaçōes: testes de ancestralidade genética em perspectiva antropológica comparada. Horizontes Antropológicos, v. 17, n. 35, p. 227-255, 2011. http://dx.doi.org/10.1590/S010471832011000100008

GIBBON, S.; NOVAS, C. Biosocialities, genetics and the social sciences: making biologies and identities. Abingdon: Routledge, 2007.

HARAWAY, D. A partilha do sofrimento: relaçôes instrumentais entre animais de laboratório e sua gente. Horizontes Antropológicos, v. 17, n. 35, p. 27-64, 2011. http://dx.doi.org/10.1590/S0104-71832011000100002

HARAWAY, D. Cyborgs and Symbionts: Living Together in the New World Order. In: GRAY, C. H. (org.). Cyborg Handbook. Nova York: Routledge, 1995. p. xi-xx.

HARAWAY, D. Primate Visions: Gender, race, and nature in the world of modern science. Nova York: Routledge, 1989.

HARAWAY, D. Simians, Cyborgs, and Women: The Reinvention of Nature. Nova York: Routledge, 1991.

HARAWAY, D. Situated Knowledges: The Science Question in Feminism and the Provilege of Partial Perspective. In: HARDING, S. (org.). The Feminist Stand Point Theory Reader: Intellectual and Political Controversies. Nova York: Routledge, 2004. p. 81-103.

HIRD, M. Feminist engagements with matter. Feminist Studies, v. 35, n. 2, p. 329-346, 2009.

HIRD, M. Sex, gender, and science. Houndmills: Palgrave, 2004.

JASANOFF, S. States of knowledge: the co-production of science and the social order. Nova York: Routledge, 2004.

JENSEN, C. B.; RÖDJE, K. (orgs.). Deleuzian Intersections: Science, Technology, Anthropology. Oxford: Berghahn Booksed, 2010.

KEITA, S. O. Y. et al. Conceptualizing Human Variation. Nature Genetics, v. 36, n. 11, p. s17-s20, 2004. https:// doi.org/10.1038/ng1455

KELLER, E. F. The century of the gene. Cambridge: Harvard University Press, 2009.

KNORR-CETINA, K. The Couch, the Cathedral and the Laboratory: On the relationship between Experiment and Laboratory in Science. In: PICKERING, A. (org.). Science as Practice and Culture. Chicago: University of Chicago Press, 1992. p. 113-138. 
KNORR-CETINA, K. The ethnographic study of scientific work: towards a constructivist interpretation of science. In: KNORR-CETINA, K.; MULKAY, M. (orgs.). Science observed: perspectives on the social study of science. Beverly Hills: Sage, 1983. p. 115-140.

LATOUR, B. Anthropology at the time of the Anthropocene - A personal view of what is to be studied. In: AMERICAN ANTHROPOLOGICAL ASSOCIATION ANNUAL MEETING. Palestra [...]. Washington, D.C., 2014.

LATOUR, B. Ciência em ação. São Paulo: Unesp, 2000.

LATOUR, B. Jamais Fomos Modernos. Rio de Janeiro: Editora 34, 1994.

LATOUR, B. Perspectivismo: "tipo" ou” bomba"? Primeiros Estudos, n. 1, p. 173-178, 2011. https://doi. org/10.11606/issn.2237-2423.v0i1p173-178

LATOUR, B. Por uma antropologia do centro. Mana, v. 10, n. 2, p. 397-413, 2004. http://dx.doi.org/10.1590/ S0104-93132004000200007

LATOUR, B.; WOOLGAR, S. A vida de laboratório: A produção dos fatos científicos. Rio de Janeiro: RelumeDumará, 1997.

LAW, J. Actor Network Theory and Material Semiotics. In: TURNER, B. (org.). The New Blackwell Companion to Social Theory. Malden: Blackwell Publishing, 2009. p. 141-158.

LAW, J.; MOL, A. (orgs.). Complexities: Social studies of knowledge practices. Durham: Duke University Press, 2002.

LIMA, B. S.; COSTA, M. C. D. Gênero, ciências e tecnologias: caminhos percorridos e novos desafios. Cadernos Pagu, n. 48, p. 1-39, 2016. http://dx.doi.org/10.1590/18094449201600480005

LOPES, M. M.; SOMBRIO, M. M. Apresentação. Cadernos Pagu, n. 49, p. 1-17, 2017. http://dx.doi.org/10.159 $0 / 18094449201700490005$

LUNA, N. From abortion to embryonic stem cell research: Biossociality and the constitution of subjects in the debate over human rights. Vibrant: Virtual Brazilian Anthropology, v. 12, n. 1, p. 167-203, 2015. http://dx.doi. org/10.1590/1809-43412015v12n1p167

MACEDO, J. L. D. The multiple meanings of "risk": views on the abortion of non-viable fetuses among Brazilian medical doctors and magistrates. Vibrant: Virtual Brazilian Anthropology, v. 12, n. 1, p. 204-230, 2015. http://dx.doi.org/10.1590/1809-43412015v12n1p204

MACHADO, P. S. (Des)fazer corpo, (re)fazer teoria: um balanço da produção acadêmica nas ciências humanas e sociais sobre intersexualidade e sua articulação com a produçáo latino-americana. Cadernos Pagu, v. 42, p. 141158, 2014. http://dx.doi.org/10.1590/0104-8333201400420141

MALINOWSKI, B. Os Argonautas do Pacífico ocidental. São Paulo: Abril, 1984.

MANICA, D. A desnaturalizaçáo da menstruação: hormônios contraceptivos e tecnociência. Horizontes Antropológicos, v. 17, n. 35, p. 197-226, 2011. http://dx.doi.org/10.1590/S0104-71832011000100007

MANICA, D.; NUCCI, M. Sob a pele: implantes subcutâneos, hormônios e gênero. Horizontes Antropológicos, v. 23, n. 47, p. 93-129, 2017. http://dx.doi.org/10.1590/s0104-71832017000100004

MARTIN, E. Anthropology and the Cultural Study of Science. Science, Technology and Human Values, v. 23, n. 1, p. 24-44, 1998. https://doi.org/10.1177\%2F016224399802300102

MCCALLUM, C. A.; ROHDEN, F. (orgs.). Corpo e saúde na mira da antropologia: ontologias, práticas, traduçóes. Salvador: EDUFBA/ABAed, 2015. 
M'CHAREK, A. Fragile differences, relational effects: Stories about the materiality of race and sex. European Journal of Women's Studies, v. 17, n. 4, p. 307-322, 2010. https://doi.org/10.1177\%2F1350506810377698

MINELLA, L. S. Temáticas prioritárias no campo de gênero e ciências no Brasil: raça/etnia, uma lacuna? Cadernos Pagu, n. 40, p. 95-140, 2013. http://dx.doi.org/10.1590/S0104-83332013000100003

MOL, A. Mind Your Plate! the Ontonorms of Dutch Dieting. Social Studies of Science, v. 43, n. 3, p. 379-396, 2013. https://doi.org/10.1177\%2F0306312712456948

MOL, A. The Body Multiple: Ontology in Medical Practice. Durham: Duke University Press, 2002.

MONTEIRO, M. Reconsiderando a etnografia da ciência e da tecnologia: tecnociência na prática. Revista Brasileira de Ciências Sociais, v. 27, n. 79, p. 139-151, 2012. http://dx.doi.org/10.1590/S0102-69092012000200009

MOSSE, D. Anti-social anthropology? Objectivity, objection, and the ethnography of public policy and professional communities. Journal of the Royal Anthropological Institute, v. 12, n. 4, p. 935-956, 2006. https://doi. org/10.1111/j.1467-9655.2006.00371.x

MOSSE, D. Notes on the ethnography of expertise and professionals in international development. In: ETHNOGRAPHY AND THE PUBLIC SPHERE, 3., 2007, Lisboa. Anais [...]. 2007.

MURA, F. De sujeitos e objetos: um ensaio crítico de antropologia da técnica e da tecnologia. Horizontes Antropológicos, v. 17, n. 36, p. 95-125, 2011. http://dx.doi.org/10.1590/S0104-71832011000200005

NEUMANN, M. A. Por uma arqueologia simétrica. Cadernos do Lepaarq, v. 5, n. 9/10, 2008. http://dx.doi. org/10.15210/lepaarq.v5i9/10.1209

NUCCI, M. Crítica feminista à ciência: das "feministas biólogas" ao caso das "neurofeministas". Estudos Feministas, v. 26, n. 1, p. 1-14, 2018. https://doi.org/10.1590/\%25x

OUDSHOORN, N. Astronauts in the sperm world: the renegotiation of masculine identities in discourses on male contraceptives. Men and Masculinities, v. 6, n. 4, p. 349-367, 2004. https://doi.org/10.1177\%2F1097184X03260959

OUDSHOORN, N. Beyond the natural body: an archeology of sex hormones. Londres: Routledge, 1994.

PALSSON, G. et al. Reconceptualizing the 'Anthropos' in the Anthropocene: Integrating the social sciences and humanities in global environmental change research. Environmental Science \& Policy, v. 28, p. 3-13, 2013. https://doi.org/10.1016/j.envsci.2012.11.004

PEREIRA, P. P. G. Limites, traduçóes e afetos: profissionais de saúde em contextos indígenas. Mana, v. 18, n. 3, p. 511-538, 2012a. http://dx.doi.org/10.1590/S0104-93132012000300004

PEREIRA, P. P. G. Variations Around Water: bodies, encounters and translation processes. Vibrant: Virtual Brazilian Anthropology, v. 9, n. 1, p. 154-180, 2012b. http://dx.doi.org/10.1590/S1809-43412012000100006

PREMEBIDA, A. Biotecnologias: Dimensões sociológicas e políticas. Jundiaí: Paco Editorial, 2011.

RABINOW, P. Antropologia da razão: ensaios de Paul Rabinow. Rio de Janeiro: Relume-Dumará, 1999.

RADOMSKY, G. F.; LEAL, O. F. From the production of rules to seed production: Global Intellectual Property and local knowledge. Vibrant: Virtual Brazilian Anthropology, v. 9, n. 1, p. 451-472, 2012. http://dx.doi. org/10.1590/S1809-43412012000100015

REUNIÁO BRASILEIRA DE ANTROPOLOGIA, 27., 2010, Belém. Anais Eletrônicos [...]. Belém: UFPA, 2010. Disponível em: <http://www.abant.org.br/conteudo/ANAIS/CD_Virtual_27_RBA/index.html>. Acesso em: 29 jan. 2019. 
REUNIÃO BRASILEIRA DE ANTROPOlOGIA, 28., 2012, São Paulo. Anais Eletrônicos [...]. São Paulo: PUCSP, 2012. Disponível em: <http://www.abant.org.br/conteudo/ANAIS/CD_Virtual_28_RBA/index.html>. Acesso em: 29 jan. 2019.

REUNIÃO BRASILEIRA DE ANTROPOLOGIA, 29., 2014, Natal. Anais Eletrônicos [...]. Brasília: Kiron, 2014. Disponível em: <http://www.abant.org.br/conteudo/ANAIS/29RBA/index.html>. Acesso em: 29 jan. 2019.

REUNiÁO BRASILEIRA DE ANTROPOlOGIA, 30., 2016, João Pessoa. Anais Eletrônicos [...]. João Pessoa: UFPB, 2016. Disponível em: <http://www.abant.org.br/conteudo/ANAIS/30rba/index.php>. Acesso em: 29 jan. 2019.

REUNIÃO BRASILEIRA DE ANTROPOLOGIA, 31., 2018, Brasília. Anais Eletrônicos [...]. Brasília: UnB, 2018. Disponível em: <http://www.evento.abant.org.br/rba/31RBA/>. Acesso em: 21 fev. 2019.

REUNIÃO DE ANTROPOLOGIA DA CIÊNCIA E TECNOLOGIA, III., 2011, Brasília. Anais Eletrônicos [...]. Brasília: UnB, 2011. Disponível em: <http://www.ige.unicamp.br/react/?q=content/ programa\%C3\%A7\%C3\%A3o-completa>. Acesso em: 29 jan. 2019.

REUNIÃO DE ANTROPOLOGIA DA CIÊNCIA E TECNOLOGIA, IV., 2013, Campinas. Anais Eletrônicos [...]. Campinas: UNICAMP, 2013. Disponível em: <https://4react.wordpress.com/>. Acesso em: 29 jan. 2019.

REUNIÃO DE ANTROPOlOGIA DA CIÊNCIA E TECNOLOGIA, V., 2015, Porto Alegre. Anais Eletrônicos [...]. Porto Alegre: UFRGS, 2015. Disponível em: <http://ocs.ige.unicamp.br/ojs/react/issue/view/70>. Acesso em: 29 jan. 2019.

REUNiÁO DE ANTROpologia DA CIÊNCIA E TECNOlOGIA, VI., 2017, São Paulo. Anais Eletrônicos [...]. São Paulo: USP, 2017. Disponível em: <https://ocs.ige.unicamp.br/ojs/react/index>. Acesso em: 29 jan. 2019.

REUNiÃO DE ANTROpOlOGia DO MERCOSUl, X., 2013, Córdoba. Anais [...].Córdoba: Editora da Universidade Nacional de Córdoba, 2013.

REUNIÃO DE ANTROPOLOGIA DO MERCOSUL, XI., 2015, Montevidéu. Anais Eletrônicos [...]. Montevidéu: UdelaR, 2015. Disponível em: <http://xiram.com.uy/>. Acesso em: 29 jan. 2019.

REUNIÃO DE ANTROPOLOGIA DO MERCOSUL, XII., 2017, Posadas. Anais Eletrônicos [...]. Posadas: UNaM, 2017. Disponível em: <https://ram2017.com.ar/?p=2144>. Acesso em: 29 jan. 2019.

RHEINBERGER, H.-J. Beyond Nature and Culture: Modes of Reasoning in the Age of Molecular Biology and Medicine. In: LOCK, M. et al. (orgs.). Living and Working with the New Medical Technologies: Intersections of Inquiry. Cambridge: Cambridge University Press, 2000. p. 19-31.

RIFIOTIS, T. Etnografia no Ciberespaço como "repovoamento" e explicação. Revista Brasileira de Ciências Sociais, v. 31, n. 90, p. 85-98, 2016. http://dx.doi.org/10.17666/319085-98/2016

RIGOTTO, R. M. Contested Knowledges in the Environmental Conflict over Uranium and Phosphate Mining in Ceará - Brazil. Vibrant: Virtual Brazilian Anthropology, v. 14, n. 2, p. 184-204, 2017. http://dx.doi. org/10.1590/1809-43412017v14n2p184

ROBERTS, C. Messengers of Sex: Hormones, biomedicine and feminism. Nova York: Cambridge University Press, 2007.

ROHDEN, F. La production d'articulations et de mouvements pour la santé des hommes au Brésil: la sexualité comme porte d'entrée. Vibrant: Virtual Brazilian Anthropology, v. 12, n. 1, p. 231-259, 2015. http://dx.doi. org/10.1590/1809-43412015v12n1p231 
ROHDEN, F. Notas para uma antropologia a partir da produção do conhecimento, os usos das ciências, intervenções e articulaçōes heterogêneas. In: FONSECA, C. et al. (orgs.). Ciências na vida: Antropologia da ciência em perspectiva. São Paulo: Terceiro Nome, 2012. p. 49-57.

ROHDEN, F. "O homem é mesmo a sua testosterona”: promoção da andropausa e representações sobre sexualidade e envelhecimento no cenário brasileiro. Horizontes Antropológicos, v. 17, n. 35, p. 161-196, 2011.

ROHDEN, F. O império dos hormônios e a construção da diferença entre os sexos. História, Ciências, SaúdeManguinhos, v. 15, supl., p. 133-152, 2008. http://dx.doi.org/10.1590/S0104-59702008000500007

ROHDEN, F. "Os hormônios te salvam de tudo": produção de subjetividades e transformaçôes corporais com o uso de recursos biomédicos. Mana, v. 24, n. 1, p. 199-229, 2018. http://dx.doi.org/10.1590/167849442018v24n1p199

ROHDEN, F. Sexual desire, testosterone and biomedical interventions: managing female sexuality in "ethical doses". Vibrant: Virtual Brazilian Anthropology, v. 14, n. 3, p. 1-12, 2017. http://dx.doi.org/10.1590/180943412017v14n3p022

ROHDEN, F.; ALZUGUIR, F. V. Desvendando sexos, produzindo gêneros e medicamentos: a promoção das descobertas científicas em torno da ocitocina. Cadernos Pagu, n. 48, p. 1-45, 2016. http://dx.doi.org/10.1590 /18094449201600480002

ROHDEN, F.; RUSSO, J.; ROCA, A. Apresentação. Horizontes Antropológicos, v. 23, n. 47, p. 9-26, 2017. http:// dx.doi.org/10.1590/s0104-71832017000100001

ROSE, N. Molecular Biopolitics, Somatic Ethics and the Spirit of Biocapital. Social Theory and Health, v. 5, n. 1, p. 3-29, 2007. https://doi.org/10.1057/palgrave.sth.8700084

SÁ, G. J. S. "Abraços de mono": elos perdidos e encontros intersubjetivos em etnografia com primatólogos no Brasil. Mana, v. 16, n. 1, p. 179-211, 2010. http://dx.doi.org/10.1590/S0104-93132010000100008

SANTOS, R. V.; GIBBON, S.; BELTRÃO, J. (orgs.). Identidades emergentes, genética e saúde: perspectivas antropológicas. Rio de Janeiro: Editora Fiocruz, 2012.

SARTI, C. Corpo e doença no trânsito de saberes. Revista Brasileira de Ciências Sociais, v. 25, n. 74, p. 77-90, 2010. http://dx.doi.org/10.1590/S0102-69092010000300005

SAUTCHUK, C. E. Ciência e Técnica. In: DUARTE, L. F. D. (org.). Horizontes das ciências sociais no Brasil: Antropologia. São Paulo: ANPOCS, 2010. p. 97-123.

SAUTCHUK, C. E. Cine-weapon: The poiesis of filming and fishing. Vibrant: Virtual Brazilian Anthropology, v. 9, n. 2, p. 406-430, 2012. http://dx.doi.org/10.1590/S1809-43412012000200015

SAUTCHUK, C. E. (org.). Técnica e transformaçáo: perspectivas antropológicas. Rio de Janeiro: ABA Publicações, 2017.

SAUTCHUK, C. E.; SAUTCHUK, J. M. Enfrentando poetas, perseguindo peixes: sobre etnografias e engajamentos. Mana, v. 20, n. 3, p. 575-602, 2014. http://dx.doi.org/10.1590/S0104-93132014000300006

SEGATA, J. La cosmopolitique de la dépression: Biosocialité dans une ethnographie multi-espèces. Vibrant: Virtual Brazilian Anthropology, v. 12, n. 1, p. 290-320, 2015. http://dx.doi.org/10.1590/1809-43412015v12n1p290

SEGATA, J. O Aedes Aegypti e o Digital. Horizontes Antropológicos, v. 23, n. 48, p. 19-48, 2017. http://dx.doi. org/10.1590/s0104-71832017000200002 
SEGATA, J.; RIFIOTIS, T. (orgs.). Políticas etnográficas no campo da cibercultura. Brasília: ABA Publicações, 2016.

SEGATA, J.; RIFIOTIS, T. (orgs.). Políticas Etnográficas no campo da ciência e das tecnologias da vida. Porto Alegre: Editora da UFRGS, 2018.

SILVA, G.; DUARTE, L. F. D. Epigênese e epigenética: as muitas vidas do vitalismo ocidental. Horizontes Antropológicos, v. 22, n. 46, p. 425-453, 2016. http://dx.doi.org/10.1590/S0104-71832016000200015

SIMÓES, J. A. A dinâmica do campo: temas, tendências e desafios. In: SIMIÃO, D.; FELDMAN-BIANCO, B. (orgs.). O campo da antropologia no Brasil: retrospectiva, alcances e desafios. Rio de Janeiro: ABA, 2018. p. 57-82.

SOUZA, I. M. A. Afeto entre humanos e animais não-humanos no biotério. Revista Brasileira de Ciências Sociais, v. 32, n. 94, p. 1-21, 2017a. http://dx.doi.org/10.17666/329407/2017

SOUZA, I. M. A. Corpos comensuráveis: produção de modelos animais na pesquisa biomédica. Horizontes Antropológicos, v. 23, n. 48, p. 275-302, 2017b. http://dx.doi.org/10.1590/s0104-71832017000200012

SPIESS, M. R.; MATTEDI, M. A. Da associaçẫo à dissolução da rede sociotécnica do processador de textos fácil: subsídios para uma etnografia da tecnologia. Mana, v. 16, n. 2, p. 435-470, 2010. http://dx.doi.org/10.1590/ S0104-93132010000200008

STENGERS, I. A proposição cosmopolítica. Revista do Instituto de Estudos Brasileiros, v. 6, n. 69, p. 442-464, 2018. https://doi.org/10.11606/issn.2316-901X.v0i69p442-464

STRATHERN, M. Cortando a rede. In: STRATHERN, M. (org.). O efeito etnográfico e outros ensaios. Sáo Paulo: Cosac Naify, 2014. p. 259-319.

STRATHERN, M. The Gender of the Gift: Problems with Women and Problems with Society in Melanesia. Berkeley: University of California Press, 1988.

TRAMONTANO, L. A fixação e a transitoriedade do gênero molecular. Horizontes Antropológicos, v. 23, n. 47, p. 163-189, 2017. http://dx.doi.org/10.1590/S0104-71832017000100006

VANDER VELDEN, F. Inquietas Companhias: sobre os animais de criaçáo entre os Karitianas. São Paulo: Alameda, 2012.

WADE, P. et al. Mestizo genomics: Race mixture, nation, and science in Latin America. Durham: Duke University Press, 2014.

WILLIAMS, S.; MARTIN, P.; GABE, J. The pharmaceuticalisation of society? A framework for analysis. Sociology of Health and Illness, v. 33, n. 5, p. 710-725, 2011. https://doi.org/10.1111/j.1467-9566.2011.01320.x

WRIGHT, R. M.; KAPFHAMMER, W.; WIIK, F. B. The Clash of Cosmographies Indigenous Societies and Project Collaboration - Three ethnographic cases (Kaingang, Sateré-Mawé, Baniwa). Vibrant: Virtual Brazilian Anthropology, v. 9, n. 1, p. 382-450, 2012. http://dx.doi.org/10.1590/S1809-43412012000100014

ZHOURI, A. Introduction: Anthropology and knowledge production in a "minefield". Vibrant: Virtual Brazilian Anthropology, v. 14, n. 2, p. 72-80, 2017. http://dx.doi.org/10.1590/1809-43412017v14n2p072 


\section{Resumo}

\section{Para além da ciência e do anthropos: deslocamentos da antropologia da ciência e da tecnologia no Brasil}

A antropologia da ciência e da tecnologia (ACT) no Brasil tem se desenvolvido com grande fôlego, principalmente a partir da virada para o século XXI. Este artigo oferece um mapeamento inicial desse campo no que concerne ao período entre 2010 e 2018. Diante das limitaçóes de fornecer um panorama mais abrangente, optamos pela combinação de diferentes estratégias: análise de publicaçóes em periódicos científicos e coletâneas; mapeamento das abordagens e temáticas presentes nos eventos científicos; e informaçóes complementares relativas a teses e dissertaçóes. Espera-se indicar pistas acerca dos investimentos de pesquisa, possivelmente mais consolidados, divulgados nas revistas mais qualificadas do país e nas coletâneas de artigos e acerca da produção emergente de conhecimento registrada nos anais dos congressos da área. Os resultados do mapeamento revelaram a concentração da produção nos seguintes eixos: conceitos e métodos da ACT; biomedicina e saúde; gêneros e sexualidades; humanos e não humanos; técnicas; questóes ambientais e desenvolvimento.

Palavras-chave: Antropologia da ciência e da tecnologia; Teoria antropológica; Etnografia; Teoria-ator-rede; Pós-humanismo.

\section{Abstract}

Beyond science and the anthropos: shifts in the anthropology of science and technology in Brazil

Anthropology of Science and Ttechnology (AST) in Brazil has developed greatly, especially since the beginning of the XXI Century. This article presents an initial mapping of this field, based on work published between 2010-2018. Given the limitations of this in offering a broader panorama of the area, we combined different strategies: analysis of articles in journals, collected volumes, together with themes emerging in scientific meetings; we also looked at master's and PhD dissertations. Through this we hope to give robust clues as to how research in the field has developed, both in its more consolidated form, in journals and books, and also at emerging topics, present in work presented at scientific events. The results of the mapping revealed the concentration of production in the following axes: ACT concepts and methods; biomedicine and health; gender and sexualities; human and non-human interactions; techniques; environmental issues and development.

Keywords: Anthropology of science and technology; Anthropological theory; Ethnography; Actor-network theory; Posthumanism.

\section{Résumé}

\section{Au-dela de la science et de l'anthropos : deplacements de l'anthropologie de la science et de la technologie au Bresil}

L'anthropologie des sciences et des technologies (ACT) au Brésil a connu un essor remarquable, en particulier depuis le début du XXIe siècle. Cet article propose une première cartographie de ce domaine pour la période allant de 2010 à 2018 . Étant donné les limites d'un aperçu plus complet, nous avons choisi la combinaison de différentes stratégies: analyse de publications dans des revues et collections scientifiques; cartographie des approches et thématiques présentes dans les événements scientifiques; informations complémentaires sur les thèses et mémoires. On fait allusion aux investissements de recherche, éventuellement plus consolidés, publiés dans les revues les plus qualifiées du pays et dans les recueils d'articles et à propos de la production émergente de connaissances consignées dans les annales des congrès de la région. Les résultats de la cartographie ont révélé la concentration de la production dans les axes suivants: concepts et méthodes d'ACT; biomédecine et santé; genres et sexualités; humain et non humain; techniques; questions environnementales et développement.

Mots-clés: Anthropologie des sciences et des technologies; Théorie anthropologique; Ethnographie; Réseau théorieacteur; Post-humanisme.

(C) 2019 Associação Nacional de Pós-Graduaçăo e Pesquisa em Ciências Sociais - ANPOCS Este é um artigo de acesso aberto distribuído nos termos de licença Creative Commons. 